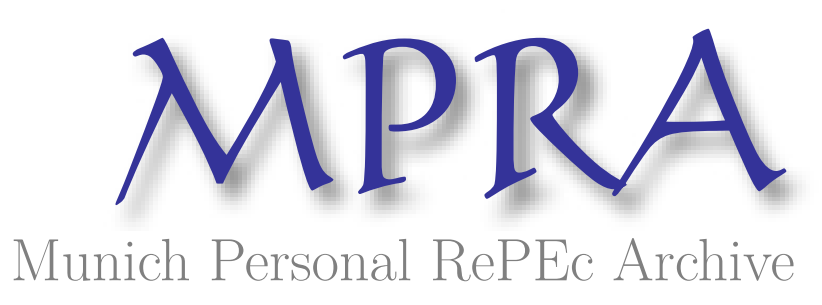

\title{
Production and Exports of Kidney Beans in the Kyrgyz Republic: Value Chain Analysis
}

Tilekeyev, Kanat and Mogilevskii, Roman and Abdrazakova, Nazgul and Dzhumaeva, Shoola

1 March 2018

Online at https://mpra.ub.uni-muenchen.de/85299/

MPRA Paper No. 85299, posted 25 Mar 2018 07:18 UTC 



\title{
Production and Exports of Kidney Beans in the Kyrgyz Republic: Value Chain Analysis
}

\author{
Kanat Tilekeyev \\ Roman Mogilevskii \\ Nazgul Abdrazakova \\ Shoola Dzhumaeva
}

\begin{abstract}
This report provides results of the study of the kidney bean (Phaseolus vulgaris) production and the marketing value chain in theykgyz Republic. The main tool of this survey is field study of farmers, dealers-wholesalers, and bean exporters with elements of quantitative and qualitative methods, as well as the results of desk analysis using open sources of information. The report analyzes agrotechnical conditions for bean production, including data on bean-related phytosanitary safety and the situation with bean-related food safety standards when exporting it and marketing problems in foreign markets. Findings of the study include the main barriers and constraints to increasing domestic production, improving bean quality and processing, and improv-ing the phytosanitary situation and food safety standards; recommendations on Kyrgyz bean market improvement are also included.
\end{abstract}

Key words: kidney beans, exports, production, value chain

JEL Codes: Q12, Q13, Q17

This work was conducted with financial support from, and under the overall guidance of, the Food and Agriculture Organization of the United Nations (FAO). 


\section{About the authors:}

Dr. Kanat Tilekeyev is a Senior Research Fellow of the Institute of Public Policy and Administration, University of Central Asia. He holds PhD in Economics from the Justus-Liebig University Giessen (Germany). He has extensive experience in research on agricultural economics, trade, business development and microeconomic studies of the countries of Central Asia

Dr. Roman Mogilevskii is a Senior Research Fellow and Associate Director of the Institute of Public Policy and Administration, University of Central Asia. He has extensive experience in research on agricultural economics, trade policy, public finance and macroeconomics of the countries of Central Asia and Eastern Europe.

Nazgul Abdrazakova is a Research Fellow at IPPA. She holds an MA in Management from the Academy of Public Administration under the President of the Kyrgyz Republic. She has experi-ence in macroeconomic analysis of Central Asian economies, regional trade, and modelling.

Shoola Dzhumaeva is currently pursuing her Master's degree in Economics at the George Wash-ington University. She used to be a Junior Research Fellow at the University of Central Asia's In-stitute of Public Policy and Administration. 


\section{Table of Contents}

1. Introduction

2. Analysis of bean production, consumption and sale ..................................................... 6

2.1. Production of kidney beans and other legumes in Kyrgyzstan ..............................................6

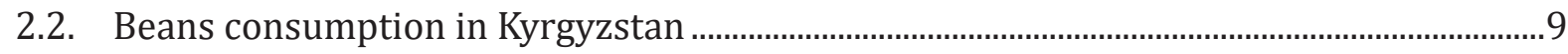

2.3. Export of beans and price information ................................................................................10

2.4. Kidney beans and development of the Talas region ............................................................13

3. Kyrgyz kidney beans value chain ..................................................................................... 13

3.1. Survey organization and methods for sampling value chain participants .......................14

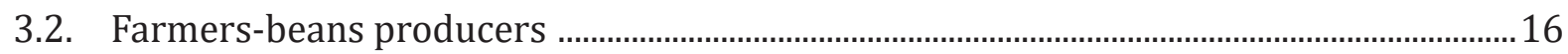

3.3. Commercial bean dealers-wholesalers …............................................................................2

3.4. Bean post-harvesting - bean cleaning workshops ….................................................................. 30

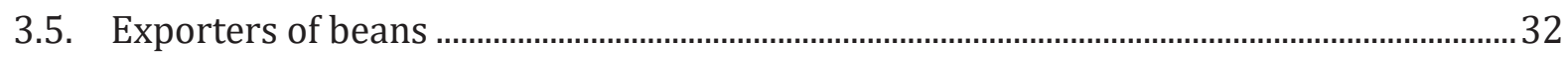

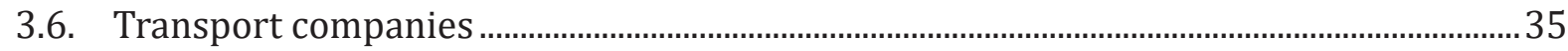

3.7. Beans value chain structure and its importance for the region's economy.......................36

4. Analysis of phytosanitary and food safety situation and beans marketing .................. 39

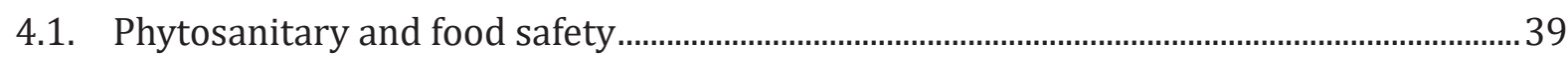

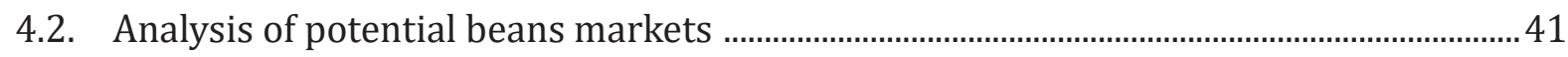

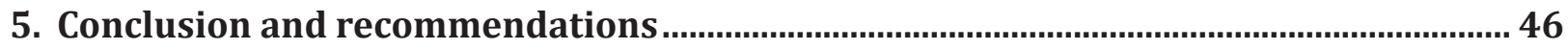

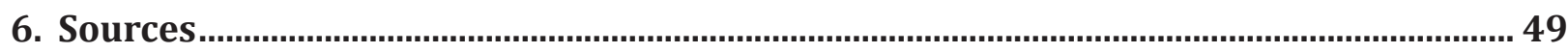

7. Annex 1 - Regulatory framework and authorized state bodies responsible for plant

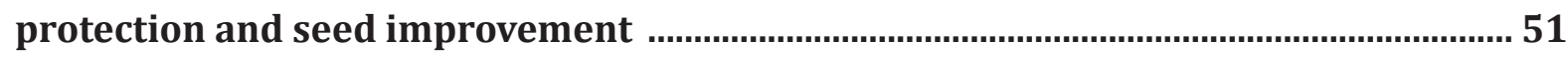

8. Annex 2 - Tariff and non-tariff barriers at potential export markets for kidney beans .... 54

\section{Tables}

Table 1. Dynamics of leguminous crops cultivation area in Kyrgyzstan with breakdown by regions in 2010-2016, ha . .8

Table 2. Structure of bean cultivation, production and yield in the Talas region in 2015 .8

Table 3. Leguminous crops production after processing in 2006-2015 in Kyrgyzstan and Talas region, thousand tons

Table 4 . Beans consumption by territory, kg per year per 1 person. 10 
Table 5. Export of goods, agricultural exports and kidney beans share in exports in 2009-2015 ....11

Table 6. Socio-economic development indicators of the Talas region in 2008-2015, \% 13

Table 7. Sampling of the value chain participants for the survey 14

Table 8. Sampling of farmers-beans producers and farmers-purveyors with breakdown by villages

Table 9. Classification of common varieties of kidney beans (Phaseolus vulgaris) in Kyrgyzstan and international varieties 18

Table 10. Availability and structure of farmers' land plots in the sample, 2011 and 2016 ..........19

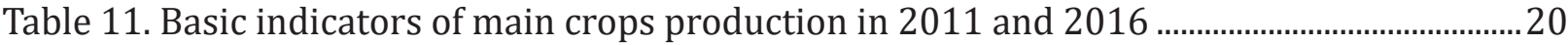

Table 12. Main indicators and the role of beans on crop sale by bean farmers in 2011 and 2016..20

Table 13. Ownership of livestock by farmers in 2011 and 2016, animal heads in the sample ...21

Table 14. Main production costs of the farmers-bean producers in 2011 .......................................22

Table 15. Main production costs of the farmers-bean producers in 2016 .23

Table 16. Estimated level of gross margin in production of beans at farmers level in 2016 and 2011

Table 17. Calculation of the gross margin effect at the farmers-bean producers level in $2016 \ldots \ldots . . .37$

Table 18. Information on the spread of bean diseases and pests in Kyrgyzstan in 2012-2015, ha..39

Table 19. Production, area and yield of the largest bean importing countries in $2014 \ldots \ldots \ldots \ldots \ldots . . . .42$

Table 20. Production, area and yield of major producers of dried beans 43

Table 21. Producer prices for dry beans, USD/ton, 2014 ……................................................................. 44

Table 22. Normative legal acts governing phytosanitary issues when exporting beans .52

Table 23. Requirements for exported products established by potential export markets (tariff and non-tariff barriers)

\section{Figures}

Figure 1. Dynamics of legumes and kidney bean cultivated area in Kyrgyzstan and Talas Oblast in 1999-2016, thousand ha

Figure 2. Export of beans from Kyrgyzstan to major markets in 2009-2015, thousand tons .....11

Figure 3. Dynamics of the domestic average consumer prices for beans in Kyrgyzstan in 20102016, KGS/kg

Figure 4. Map of the Talas region 14

Figure 5. Example of the sample of farmers-beans producers and farmers-purveyors in one of the villages 
Figure 6. Average price for beans at the level of farmers-bean producers and farmers-purveyors in 2015-2017, KGS/kg .25

Figure 7. Examples of ready-packed beans (February 2017) 27

Figure 8. Manual bean cleaning 27

Figure 9. Beans prices at wholesalers level in 2015-2016, KGS/kg 30

Figure 10. Small beans cleaning workshop operation (February 2017) 31

Figure 11. Large beans cleaning workshop operation (February 2017) 32

Figure 12. Beans prices at the exporting firms level in 2015-2016, KGS/kg . 34

Figure 13. Average prices at the farmers (farmers-beans producers and farmers-purveyors), wholesalers and exporters levels by periods in 2015-2016, KGS/kg ..... 34

Figure 14. Value Chain Scheme. .37

Figure 15. Approximate calculation of the gross margin distribution among the value chain participants 38

Figure 16. Import of beans in 2015 by the largest importers 41

Figure 17. The largest beans exporting countries in 2015 43

Figure 18. Options for cargo delivery from Kyrgyzstan to South Korea and Pakistan. 45

\section{Abbreviations}

$\begin{array}{ll}\text { CU } & \text { Customs Union } \\ \text { DPCPPQ } & \text { State department for Plant Chemicalization, Plant Protection and Quarantine } \\ \text { EAEU } & \text { Eurasian Economic Union } \\ \text { EU } & \text { European Union } \\ \text { FEACN } & \text { Foreign Economic Activity Commodity Nomenclature } \\ \text { GoKR } & \text { Government of the Kyrgyz Republic } \\ \text { ISTA } & \text { International association for testing seeds } \\ \text { ILO } & \text { International labour organization } \\ \text { IFPRI } & \text { International Food Policy Research Institute } \\ \text { KIHS } & \text { Kyrgyz Integrated Household Survey } \\ \text { LLC } & \text { Limited Liability Company } \\ \text { MAFIR KR } & \text { Ministry of Agriculture, Food Industry and Land Reclamation of the Kyrgyz Republic } \\ \text { NLA } & \text { Normative legal acts } \\ \text { NSC } & \text { National Statistical Committee of the Kyrgyz Republic } \\ \text { RSSI } & \text { Republican State Seed Inspection } \\ \text { SAK } & \text { Seed Association of Kyrgyzstan } \\ \text { IE } & \text { Individual Entrepreneur } \\ \text { TIR } & \text { International Road Transportation } \\ \text { UCT EAEU } & \text { Unified system of tariff preferences of the Eurasian Economic Union } \\ \text { UN ESCAP } & \text { The United Nations Economic and Social Commission for Asia and the Pacific }\end{array}$




\section{Introduction}

This report provides results of the study of the kidney bean (Phaseolus vulgaris) production and the marketing value chain in the Kyrgyz Republic. Leguminous crops historically have not been widely spread in Kyrgyzstan and accounted for a small share in agricultural production. However, since the early 2000s its share has increased significantly due to a sharp increase in bean production and export. This phenomenon is regional in nature - kidney bean cultivated in the Talas region accounts for over $90 \%$ of all leguminous crops grown in the country ${ }^{1}$. Over the past few years, bean has continuously been the third most important export commodity in Kyrgyzstan following gold and oil products and the first most important exported agricultural product. This phenomenon need to be explored in details, and our research provides the results of our study on how and where bean is cultivated in Kyrgyzstan and exported along the value-added production and marketing chain, as well as problems faced by this crop producers and value chain agents now and in the long term. This research was conducted by the Institute of Public Policy and Administration of the University of Central Asia (IPPA UCA) supported by the Food and Agriculture Organization of the United Nations (FAO).

The main tool of this survey is field study with elements of quantitative and qualitative methods, as well as the results of desk analysis using open sources of information.

The report consists of the following chapters: Chapter 2 provides an overview of the current bean-related market context and trends in the Kyrgyz Republic (production, consumption, foreign trade, prices and other related information) using official statistics. Chapter 3 provides findings of the survey among farmers - bean producers, resellers and exporters from Kyrgyzstan to foreign markets focusing on the description of organizational and institutional aspects of the bean value chain, as well as analysis of the production cycle of bean cultivation and post-harvest processing. Chapter 4 describes agrotechnical conditions for bean production, including data on bean-related phytosanitary safety and the situation with bean-related food safety standards when exporting it and marketing problems in foreign markets. Chapter 5 provides findings of surveying the main barriers and constraints to increasing domestic production, improving bean quality and processing, and improving the phytosanitary situation and food safety standards.

\section{Analysis of bean production, consumption and sale}

\subsection{Production of kidney beans and other legumes in Kyrgyzstan}

Kidney bean is a relatively new crop in Kyrgyzstan. Other types of legumes (peas and soybean) were historically cultivated in Kyrgyzstan, with production concentration in the southern regions of the country. Starting from the late 1990s, bean production was growing increasingly in the Talas region with a targeted orientation towards exports to Turkey. At the end of 2000, 80\% of the country's leguminous crops were produced in the Talas region, and in subsequent years this share has increased to $92-95 \%$ and has since not decreased below this indicator.

According to available data, bean as an export crop was initiated in Talas thanks to the efforts of representatives of the Turkish firm "Robin" in 1995 on an area of 230 hectares. ${ }^{2}$ Initially bean

$1 \quad$ Tilekeyev, K (2013). Productivity Implications of Participation in Export Activity: The case of Farmers in Talas Oblast of. University of Central Asia, Working Paper No. 17.

2 M. A. Bolotova (2010). Development of the agrarian sector of the economy in the market conditions (using Talas region as an example) - dissertation for the degree of Candidate of Economic Sciences, J. Balasagyn KNU 
was cultivated in the Kara-Buura district densely populated by Kurds. ${ }^{3}$ Kurds constitute an ethnic minority (2.5\% of the population in this region) ${ }^{4}$ living in the Kara-Buura and Manas districts. It should be noted that bean was cultivated by Kurds already prior to the arrival of the Turkish companies. Kurds were cultivating bean in small quantities for domestic consumption and sales to representatives of their diaspora in Uzbekistan. Gradually, with sustainable demand for bean and an increase in purchase prices after the emergence of other competitive firms, Kyrgyz farmers have also started to cultivate bean in increasing quantities. Sustainable demand for bean from Turkish exporting firms for a number of years has played a key role in bean spread as the main crop of the region. In some places this happened at the end of the 1990s; however, on the whole, bean was widely spread only after 2005 .

Currently, bean is cultivated in the Talas region on an area of 53,000 hectares, while the historical maximum area of 55,000 hectares was observed in 2014 (see Figure 1). The main reason for the sharp growth in bean cultivation in the region is the export dimension of the product and, therefore, its profitability for small-scale farmers.

\section{Figure 1. Dynamics of legumes and kidney bean cultivated area in Kyrgyzstan and Talas Oblast in 1999-2016, thousand ha}

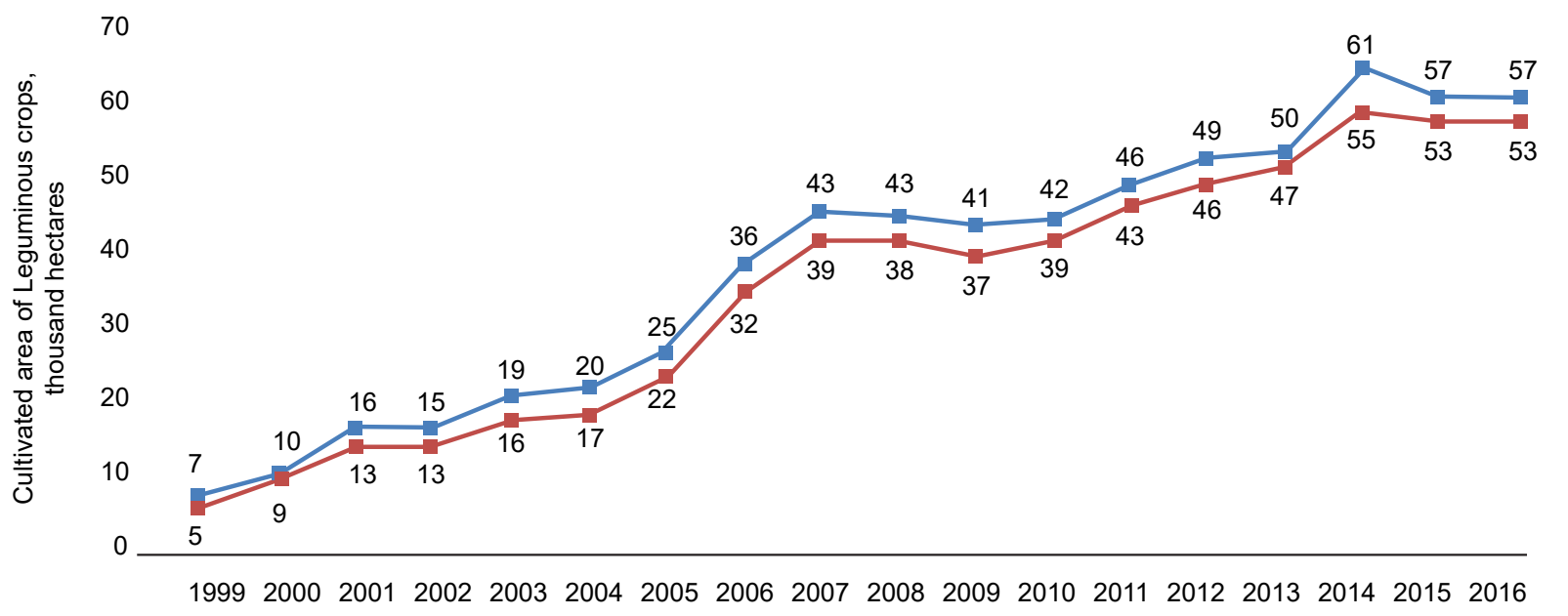

Source: National Statistical Committee (NSC) of the Kyrgyz Republic

By 2007, bean took its niche in the Talas regional economy and became an important export commodity for the agricultural sector. The most significant shift in the cultivation areas of the leguminous crops was in 2000, 2001, 2006 and 2014, when the area under legumes increased by $49 \%, 57 \%, 46 \%$ and $23 \%$ compared to previous years, respectively. This is primarily due to

3 Kurds were interned in Kyrgyzstan and other republics of Central Asia from the Caucasian republics of the USSR in the 30s of the 20th century during the Stalinist repressions. (See J. Minahan The former Soviet Union's diverse people: a reference sourcebook, ABC-Clio, 2004)

$4 \quad$ NSC (2010). The 2009 Population and Housing Fund Census of KR. Book 3. Talas Region, Bishkek 
spasmodic increases in the bean purchase price. During this period the bean cultivation area increased on average by $15 \%$ per year.

According to the recent data, ${ }^{5}$ the Talas region accounted for $93 \%$ of the leguminous crops cultivation area (see Table 1). The second most important region is the Batken region (3.4\% of leguminous crops). In other regions, leguminous crops cultivation area either does not exceed several hundreds of hectares or leguminous crops are not cultivated at all.

Table 1. Dynamics of leguminous crops cultivation area in Kyrgyzstan with breakdown by regions in 2010-2016, ha

\begin{tabular}{|c|c|c|c|c|c|c|c|}
\hline Regions & 2010 & 2011 & 2012 & 2013 & 2014 & 2015 & 2016 \\
\hline Batken & 1747 & 1684 & 1809 & 1791 & 2082 & 1914 & 1915 \\
\hline Jalal-Abad & 828 & 847 & 1071 & 906 & 1502 & 981 & 656 \\
\hline Issyk-Kul & 147 & 141 & 123 & 46 & 311 & 411 & 488 \\
\hline Chui & 525 & 447 & 306 & 150 & 1752 & 970 & 606 \\
\hline Talas & 38628 & 42776 & 45666 & 46726 & 54880 & 53036 & 52840 \\
\hline Other & 269 & 258 & 258 & 255 & 620 & 15 & 15 \\
\hline Kyrgyz Republic & 42144 & 46,153 & 49233 & 49874 & 61147 & 57327 & 56520 \\
\hline
\end{tabular}

Source: National Statistical Committee (NSC), Ministry of Agriculture, Processing Industry and Melioration

Table 2. Structure of bean cultivation, production and yield in the Talas region in 2015

\begin{tabular}{|c|c|c|c|c|}
\hline & \multicolumn{2}{|c|}{ Area } & \multirow[b]{2}{*}{$\begin{array}{l}\text { Production, } \\
\text { thousand tons }\end{array}$} & \multirow[b]{2}{*}{$\begin{array}{c}\text { Net yield, tons / } \\
\text { ha }\end{array}$} \\
\hline & $\mathrm{Ha}$ & $\begin{array}{c}\% \text { of } \\
\text { cultivated } \\
\text { area in the } \\
\text { district }\end{array}$ & & \\
\hline Bakai-Ata district & 16568 & 67.8 & 25.7 & 1.55 \\
\hline Kara-Buura district & 22327 & 66.6 & 30.5 & 1.36 \\
\hline Manas district & 3473 & 20.5 & 3.8 & 1.09 \\
\hline Talas district $^{7}$ & 10668 & 37.1 & 14.4 & 1.34 \\
\hline Talas Oblast & 53036 & 50.8 & 74.4 & 1.4 \\
\hline
\end{tabular}

Source: National Statistical Committee (NSC)

The main areas of production in this region are concentrated in two districts - Bakai-Ata and Kara-Buura occupying $32 \%$ and $43 \%$ of the total area under bean in the region, respectively. The main part of the cultivated area in these two districts is in the middle altitude zone in the region

$5 \quad$ Overview of the agricultural crops harvesting of by regions and districts of the Kyrgyz Republic as of September 24, 2016, Ministry of Agriculture, Processing Industry and Land Reclamation of the Kyrgyz Republic

$6 \quad$ In the cleaned weight, excluding culling and sorting. For example total yield in 2015 was 89.7 thousand ton (20.5\% higher)

$7 \quad$ Including Talas town area 
at the level of 1000-1400 m above sea level. The Talas district and Talas city are in general slightly higher being in a more mountainous zone, while Manas district is in the lower zone being at the level of the adjacent Kazakhstani territories. ${ }^{8}$

Table 3. Leguminous crops production after processing in 20062015 in Kyrgyzstan and Talas region, thousand tons

\begin{tabular}{|c|c|c|c|c|c|c|c|c|c|c|}
\hline & $\mathbf{2 0 0 6}$ & $\mathbf{2 0 0 7}$ & $\mathbf{2 0 0 8}$ & $\mathbf{2 0 0 9}$ & $\mathbf{2 0 1 0}$ & $\mathbf{2 0 1 1}$ & $\mathbf{2 0 1 2}$ & $\mathbf{2 0 1 3}$ & $\mathbf{2 0 1 4}$ & $\mathbf{2 0 1 5}$ \\
\hline $\begin{array}{c}\text { Talas region, } \\
\text { thousand tons }\end{array}$ & 52.2 & 66.7 & 64.3 & 63.7 & 68 & 70.8 & 75.1 & 79.9 & 80.8 & 89.7 \\
\hline $\begin{array}{c}\text { Kyrgyz Republic, } \\
\text { thousand tons }\end{array}$ & 58.2 & 73.5 & 70.9 & 71.3 & 73.6 & 76.1 & 81.3 & 84.9 & 90.1 & 96.7 \\
\hline $\begin{array}{c}\text { Talas region, \% of } \\
\text { the total production } \\
\text { in the country }\end{array}$ & $90 \%$ & $91 \%$ & $91 \%$ & $89 \%$ & $92 \%$ & $93 \%$ & $92 \%$ & $94 \%$ & $90 \%$ & $93 \%$ \\
\hline
\end{tabular}

Source: NSC

In the past decade, the Talas region produced $90-94 \%$ of all leguminous crops in the country. In 2016, the total agricultural land share allotted for beans amounted to $50.4 \%$ of the total arable land in the Talas region, and $4.7 \%$ of all crops in Kyrgyzstan. In 2006, these figures were significantly lower - 32\% and 3.2\%, respectively. In addition to beans, the Talas region also produces potatoes, grain (wheat, grain maize and barley), vegetables, hay of perennial grasses, oil-bearing crops, and fruit and berries.

In general, the leguminous crops yield is quite homogeneous throughout the country, and is on average 1.7 tons/ha. The yield in the Issyk-Kul region is slightly higher than the country average - up to 2 tons/ha. At the same time, there was a slight decrease in the beans yield compared to the yield as at the beginning of the century (1999-2000), when the average yield was 1.9-2 tons per 1 ha.

$96 \%$ of legumes are cultivated by peasant farms (farmers) ${ }^{9}$. In general, the gross yield of legumes increased more than 5-fold over 15 years (2000-2015). Since the yield for the period concerned has not increased, but on the contrary has somewhat decreased, the legumes production growth was extensive due to a significant increase in the areas under beans in Talas. Beans play a significant role in the region and have become a monoculture, while at the country level it has become a notable crop, being one of the country's ten most important crops.

\subsection{Beans consumption in Kyrgyzstan}

Legumes are characterized by their high protein content. In terms of nutritional value, 250 grams of beans are equal to 100 grams of mutton or 3 chicken eggs. However, despite the useful properties of legumes, their consumption among the population of Kyrgyzstan is very low and they are reluctantly included in the diet.

$8 \quad$ Tilekeyev, K (2013). Productivity Implications of Participation in Export Activity: The case of Farmers in Talas Oblast of. University of Central Asia, Working Paper No. 17.

$9 \quad$ NSC (2015) Kyrgyzstan in figures 
Table 4. Beans consumption by territory, kg per year per 1 person

\begin{tabular}{|c|c|c|c|c|}
\hline & 2011 & 2012 & 2013 & 2014 \\
\hline Kyrgyz Republic & 0.39 & 0.21 & 0.16 & 0.18 \\
\hline Batken region & 1.08 & 0.65 & 0.48 & 0.56 \\
\hline Jalal-Abad region & 0.41 & 0.21 & 0.20 & 0.21 \\
\hline Issyk-Kul region & 0.10 & 0.09 & 0.06 & 0.09 \\
\hline Naryn region & 0.01 & 0.00 & 0.02 & 0.02 \\
\hline Osh region & 0.42 & 0.05 & 0.01 & 0.06 \\
\hline Talas region & 0.05 & 0.05 & 0.04 & 0.08 \\
\hline Chui region & 0.34 & 0.41 & 0.16 & 0.19 \\
\hline Bishkek & 0.39 & 0.22 & 0.10 & 0.20 \\
\hline
\end{tabular}

Source: 2011-2014 Integrated Household Survey, NSC of KR; authors' calculations

According to the Kyrgyz Integrated Household Survey, bean consumption ranges from 0.18 to $0.39 \mathrm{~kg}$ per person per year. The highest consumption is in the southern regions of the republic Batken and Jalal-Abad regions and Osh city. For instance, bean consumption in the Batken region varies from $560 \mathrm{~g}$ to $1 \mathrm{~kg}$ per person per year. In addition, a slightly above the national average or the average bean consumption is in Bishkek and Chui region. Beans are virtually not consumed in the Naryn region.

The consumption of other legumes such as peas is slightly higher; however, this also does not exceed an average of $1 \mathrm{~kg}$ per year per person in the country. In 2014, the average consumption of peas was $0.72 \mathrm{~kg}$ per person. The highest consumption of peas is in Chui, Issyk-Kul, Talas regions and Bishkek and exceeds or is equal to $1 \mathrm{~kg}$ per person per year. In Naryn and Osh regions, the consumption of peas per person per year is $0.12 \mathrm{~kg}$ and $0.10 \mathrm{~kg}$, respectively. According to FAOSTAT $^{10}$, beans supply in Kyrgyzstan in 2013 was $4.74 \mathrm{~kg}$ per person per year. However, consumption does not exceed $3.5 \%$ of supply. In general, the legumes consumption dynamics is stable and there is no significant change in culture and eating habits towards any increase in legumes consumption.

\subsection{Export of beans and price information}

In 2009-2014, on average, 13-16 \% of the country's total exports accounted for agricultural goods. In 2015, there was a general reduction in exports, including the export of agricultural goods. The share of agricultural exports in total exports decreased to $11 \%$ (see Table 5).

In 2009, beans accounted for $16 \%$ of agricultural exports. By 2015, the share of beans increased to $26 \%$ against the general decline in exports of agricultural products. The share of beans export in the total export of the Talas region is $92-96 \%$, and as a result beans are the region's main export commodity ${ }^{11}$. In 2009-2015, Kyrgyzstan exported 50,000 to 65,000 tons of beans annually.

\footnotetext{
10 Food and Agriculture Organization of the United Nations (2013). The statistical database FAOSTAT. http:// www.fao.org/faostat/en/\#data/TP.

11 NSC (2015) Foreign Trade of the Kyrgyz Republic 2010-2014.
} 
Table 5. Export of goods, agricultural exports and kidney beans share in exports in 2009-2015

\begin{tabular}{|c|c|c|c|c|c|c|c|}
\hline & 2009 & 2010 & 2011 & 2012 & 2013 & $2014 *$ & 2015 \\
\hline Export of goods, mln. USD & $1,178.3$ & $1,488.4$ & $1,978.9$ & $1,683.2$ & $1,773.2$ & $1,640.6$ & $1,441.5$ \\
\hline $\begin{array}{c}\text { Export of agricultural } \\
\text { products (WTO_H3_Aggri } \\
\text { product group) }\end{array}$ & 182.4 & 225.2 & 261.7 & 265.8 & 268.6 & 242.6 & 165.4 \\
\hline $\begin{array}{c}\text { Share of agricultural } \\
\text { goods in the total export } \\
\text { structure, \% }\end{array}$ & $15 \%$ & $15 \%$ & $13 \%$ & $16 \%$ & $15 \%$ & $15 \%$ & $11 \%$ \\
\hline $\begin{array}{c}\text { Export of beans (HS code } \\
\text { 071333), mln. USD }\end{array}$ & 29.6 & 35.1 & 51.8 & 48.2 & 73 & 62 & 43.7 \\
\hline $\begin{array}{c}\text { Export of beans (code } \\
\text { 071333), thousand tons }\end{array}$ & 53.3 & 57 & 76.4 & 61.4 & 61.7 & 53.1 & 66.7 \\
\hline $\begin{array}{c}\text { Share of beans in the } \\
\text { export of agricultural } \\
\text { products, \% }\end{array}$ & $16 \%$ & $16 \%$ & $20 \%$ & $18 \%$ & $27 \%$ & $26 \%$ & $26 \%$ \\
\hline
\end{tabular}

Source: UNCOMTRADE, * The State Customs Service under the Government of the Kyrgyz Republic

Figure 2. Export of beans from Kyrgyzstan to major markets in 2009-2015

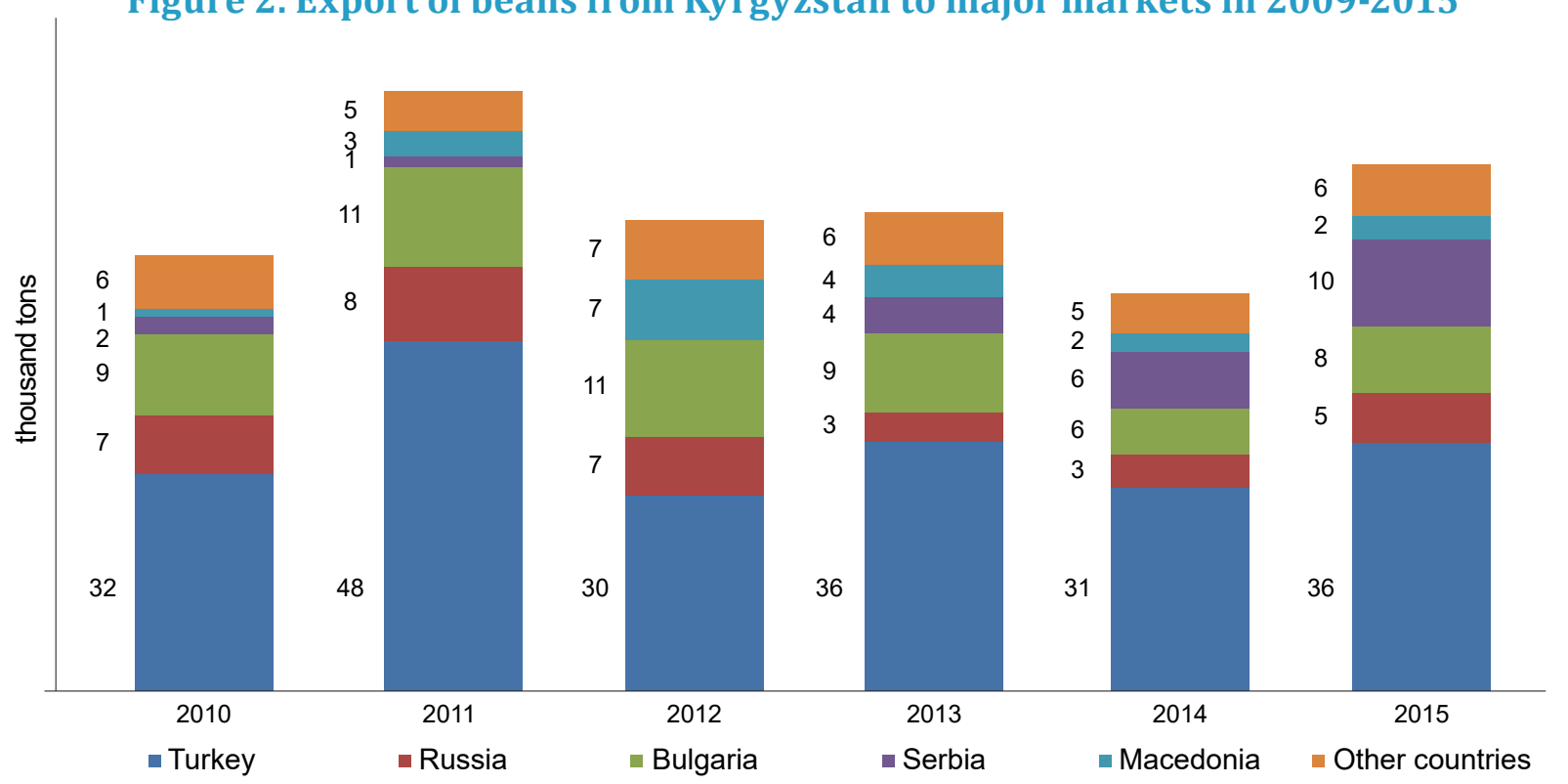

Source: UNCOMTRADE, the State Customs Service under the Government of the Kyrgyz Republic ${ }^{13}$

Most of the harvested beans are exported to countries such as Turkey and Balkan countries in Europe (Bulgaria, Macedonia and Serbia), as well as to Russia (see Figure 2). Supply to other countries varies depending on the year and is unstable. Purchase prices for Kyrgyz beans significantly depend on the situation in the global market. For example, yield in China, Argentina, Egypt

12 WTO_H3_Agrii: this category includes the groups 01-02, 04-24 plus some products of the groups 29, 33, 35, 38, 41, 43, 50-53 of the Harmonized System (HS).

13 State Customs Service under the Government of the Kyrgyz Republic (2014). The collection "Customs statistics of foreign trade", http://www.customs.kg/index.php/kg/custstat/115-sbtamstvntr/130-sbstsvntr 
and other major bean exporters, demand in Turkey and the Balkans, as well as currency fluctuations significantly affect purchase price and therefore the bean market in Kyrgyzstan.

In 2013, the prices for beans peaked, when purchase prices increased to $100-120 \mathrm{som} / \mathrm{kg}$ at some points and Kyrgyz beans were exported to 17 countries across the world ${ }^{14}$. The main reason for this sharp increase was a shortage of beans due to low supply by key exporters. In 2013, climatic conditions damaged the yield in Argentina and Turkey (drought and frost, respectively). At the same time, political instability in Egypt intensified, and areas under beans in China decreased, thus contributing to the record price increase for beans. ${ }^{15}$

Subsequently, at the beginning of 2014, the price was $70 \mathrm{KGS} / \mathrm{kg}$, which then fell to $45-60 \mathrm{KGS} /$ $\mathrm{kg}$. In 2015, the price fell even lower: to 33-35 KGS/kg. These fluctuations in prices were due to a good yield and increase in supplies from the major exporters: China and countries of South America ${ }^{16}$. The introduction of customs duties of $19.3 \%$ on the imported beans by Turkey in 2014 contributed to the reduction in purchase price for Kyrgyz beans. Given that a significant portion of beans is exported to Turkey, the impact of these changes on the purchase price was noticeable. A reduction in purchase prices for beans entailed a certain reduction in the areas under beans, both in the country and in the region in 2015-2016. (See Figure 1).

Kyrgyz beans are sold at the commodity exchange of the Turkish city of Mersin ${ }^{17}$. According to the Ministry of Agriculture, a group of Kyrgyz exporters visited this exchange at Mersin in the framework of training and promotion of Kyrgyz beans for exports. ${ }^{18}$

It should be noted that since beans production and sales have a pronounced regional nature, fluctuations in prices for beans do not correlate with fluctuations in prices for beans in the consumer market of the country (see Figure 3). Beans in other parts of Kyrgyzstan are generally sold at a price higher than in Talas. This is due to two factors - low domestic consumption in general in the country and export-oriented supplies in Talas.

\section{Figure 3. Dynamics of the domestic average consumer prices for beans in Kyrgyzstan in 2010-2016, KGS/kg}

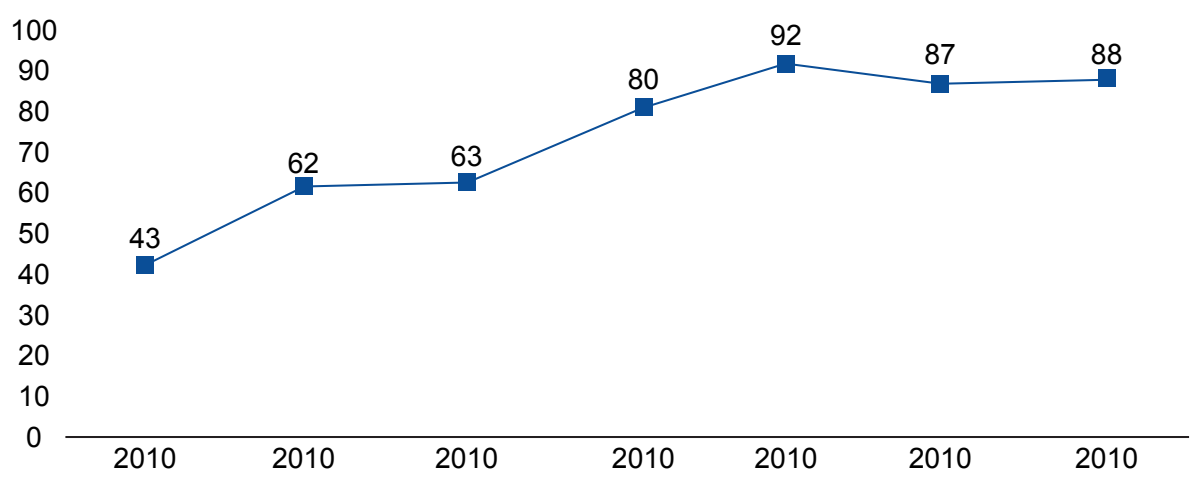

Source: NSC

14 Anara Bakytbekova (2016). Growing prices for beans. http://vwww.gezitter.org/economics/53573

15 Victoria Prediger (2016). Talas beans - a victim of world geopolitics? http://www.vesti.kg/index.php?option=com

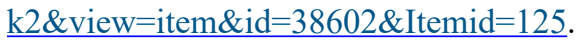

16 Iskender Sharsheev, (2016). Talas beans are a struggle for world markets http://caa-network.org/archives/7555.

17 Tatiana Kudryavtseva (2015). The Prime Minister called on Kyrgyz people to eat more beans; https://24.kg/ obschestvo/22728_premer-ministr_prizval_kyirgyizstantsev_est_bolshe_fasoli.

18 This information was presented at the seminar during the presentation of the preliminary version of the report on February 28, 2017. 


\subsection{Kidney beans and development of the Talas region}

An indirect impact of the development of the bean sector has come in the form of an improvement to a number of socio-economic indicators of regional development (see Table 6). In the past three years, poverty levels in the region have significantly decreased - at the moment, the Talas region is the least poor region in the country with a poverty rate one third lower than the national average. Unemployment has also significantly decreased in this region and employment has increased. The employment rate in Talas is $16 \%$ higher than throughout the country, while the unemployment rate is more than twice lower than the national average.

In addition to positive trends, some negative social factors should also be noted. In the Talas region, there was a sharp increase in the child labour level in Kyrgyzstan - from 10.3\% to 29.6\% in 2007-2014. The number of children, who do not attend school, is increasing. Every child who does not attend school in the Talas region works ${ }^{19}$. There is no evidence of a direct link between an increase in bean production in the region and child labour growth, but given the profitability of the cultivation and post-harvested processing of beans and the high levels of manual labour required, this trend can be realistic. This negative impact can have far-reaching consequences for the future education and health status of the population of the region.

Table 6. Socio-economic development indicators of the Talas region in 2008-2015, \%

\begin{tabular}{|c|c|c|c|c|c|c|c|c|c|}
\hline \multicolumn{2}{|c|}{} & 2008 & 2009 & 2010 & 2011 & 2012 & 2013 & 2014 & 2015 \\
\hline Poverty rate & $\begin{array}{c}\text { Kyrgyz } \\
\text { Republic }\end{array}$ & 31.7 & 31.7 & 33.7 & 36.8 & 38.0 & 37.0 & 30.6 & 32.1 \\
\cline { 2 - 10 } & Talas region & 43.0 & 33.0 & 42.3 & 50.2 & 39.6 & 23.1 & 19.0 & 21.5 \\
\hline $\begin{array}{c}\text { Employment } \\
\text { rate }\end{array}$ & $\begin{array}{c}\text { Kyrgyz } \\
\text { Republic }\end{array}$ & 60 & 59 & 58.6 & 59.3 & 58.8 & 57.3 & 57.3 & 57.7 \\
\cline { 2 - 10 } & Talas region & 66.9 & 67.5 & 68 & 67.5 & 66.6 & 67.8 & 73.2 & 74.1 \\
\hline $\begin{array}{c}\text { Unemploy- } \\
\text { ment rate }\end{array}$ & $\begin{array}{c}\text { Kyrgyz } \\
\text { Republic }\end{array}$ & 8.2 & 8.4 & 8.6 & 8.5 & 8.4 & 8.3 & 8 & 7.6 \\
\cline { 2 - 11 } & Talas region & 5.4 & 4.9 & 5.1 & 5 & 4.1 & 3.7 & 3.9 & 3.3 \\
\hline
\end{tabular}

Source: NSC

\section{Kyrgyz kidney beans value chain}

Chapter 3 provides key findings of the survey among farmers-bean producers, as well as those who are involved in the purchase of beans and their subsequent resale (hereinafter - "purveyors"), commercial bean dealers, bean exporters from Kyrgyzstan to foreign markets, as well as bean cleaning workshops and transport companies, with a focus on organizational and institutional aspects of the beans value chain, as well as an analysis of the production cycle of bean cultivation and its post-harvest processing.

19 International Labor Office, NSC (2016). Working children in the Kyrgyz Republic. Survey of child labor 20142015. BISHKEK: ILO 


\subsection{Survey organization and methods for sampling value chain participants}

This survey is a qualitative study with elements of quantitative methods. Survey period: November 2016 - January 2017. Farmers in the Talas region are the backbone of the value chain with $75 \%$ of all beans in the region being produced in two districts - Kara-Buura and Bakai-Ata districts (see Figure 4).

Figure 4. Map of the Talas region

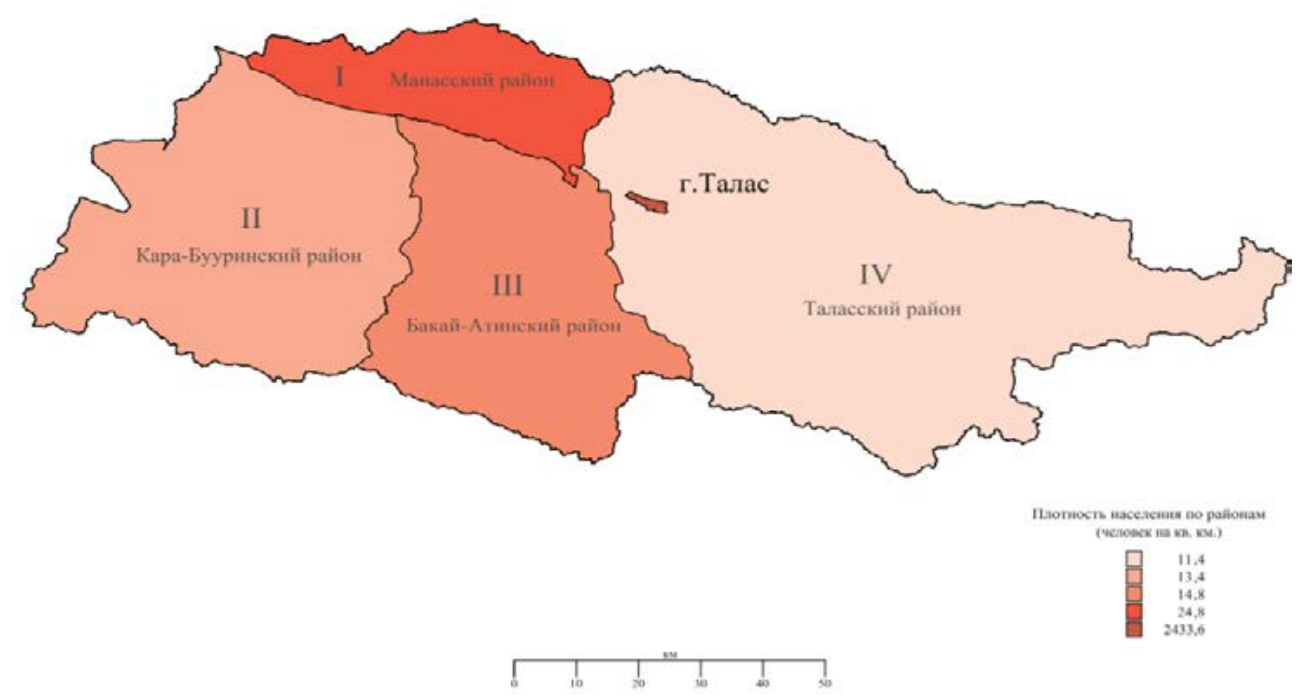

Source: NSC, 2009 Population Census

These two districts occupy $53 \%$ of the territory of the region 20 with nearly 115,000 people $(53 \%$ of the region's population) living in 18 aiyl aimaks [rural municipalities], in 41 villages 21 . Data for the survey were collected mainly in these two districts. The survey period was quite short. Survey was done in October 2016- January 2017. 70 respondents in total was covered.

Table 7. Sampling of the value chain participants for the survey

\begin{tabular}{|c|c|c|c|}
\hline \multirow{2}{*}{} & \multirow{2}{*}{ Total } & \multicolumn{2}{|c|}{ including } \\
\cline { 3 - 4 } & 40 & Kara-Buura district & Bakay-Ata district \\
\hline Farmers & 10 & 20 & 20 \\
\hline Farmers-purveyors & 10 & 5 & 5 \\
\hline Commercial resellers wholesalers & 5 & 5 & 5 \\
\hline Exporters & 2 & 2 & - \\
\hline Transport agents & 3 & 3 & - \\
\hline Beans cleaning workshop & 70 & 42 & 28 \\
\hline Total & & & \\
\hline
\end{tabular}

Source: survey data

20 NSC (2010). 2009 Population and Housing Fund Census of the Kyrgyz Republic. Book 3. Talas region.

21 NSC (2016). The rural population according to data of aiyl okmotu as of the beginning of 2016. 
Table 8. Sampling of farmers-beans producers and farmerspurveyors with breakdown by villages

\begin{tabular}{|c|c|c|c|}
\hline \multirow{1}{*}{ District } & Village & $\begin{array}{c}\text { Farmers-beans } \\
\text { producers }\end{array}$ & $\begin{array}{c}\text { Farmers } \\
\text {-purveyors }\end{array}$ \\
\hline \multirow{4}{*}{ Kara-Buura district } & Amanbaevo & 7 & 3 \\
\cline { 2 - 4 } & Bakyyan & 3 & 1 \\
\cline { 2 - 4 } & Chymgent & 6 & 1 \\
\cline { 2 - 4 } & Uch-Bulak & 4 & 2 \\
\hline \multirow{4}{*}{ Bakay-Ata district } & Bakay-Ata & 4 & 2 \\
\cline { 2 - 4 } & Ak-Dobo & 7 & \\
\cline { 2 - 4 } & Min-Bulak & 3 & 1 \\
\cline { 2 - 4 } & Madaniyat & 2 & 10 \\
\cline { 2 - 4 } & Kyzyl-Say & 2 & \\
\cline { 2 - 4 } & Urmaral & 40 & \\
\hline & Total & & \\
\hline
\end{tabular}

Source: survey data

Different sampling methods were applied to bean producers and the remaining survey participants. Farmers-purveyors, commercial bean resellers (wholesalers), exporters, bean-cleaning workshops and transport companies were selected using the snowball method.

The qualitative panel survey method was applied to bean producers. The lead author of this report previously conducted a survey in the Talas region at the household level in 2011 as part of their thesis paper. The sample was representative at the region and district levels and comprised 297 households. In addition, the results of this work were previously used in other publications ${ }^{22,23}$.

Figure 5. Example of the sample of farmers-beans producers and farmers-purveyors in one of the villages ${ }^{24}$

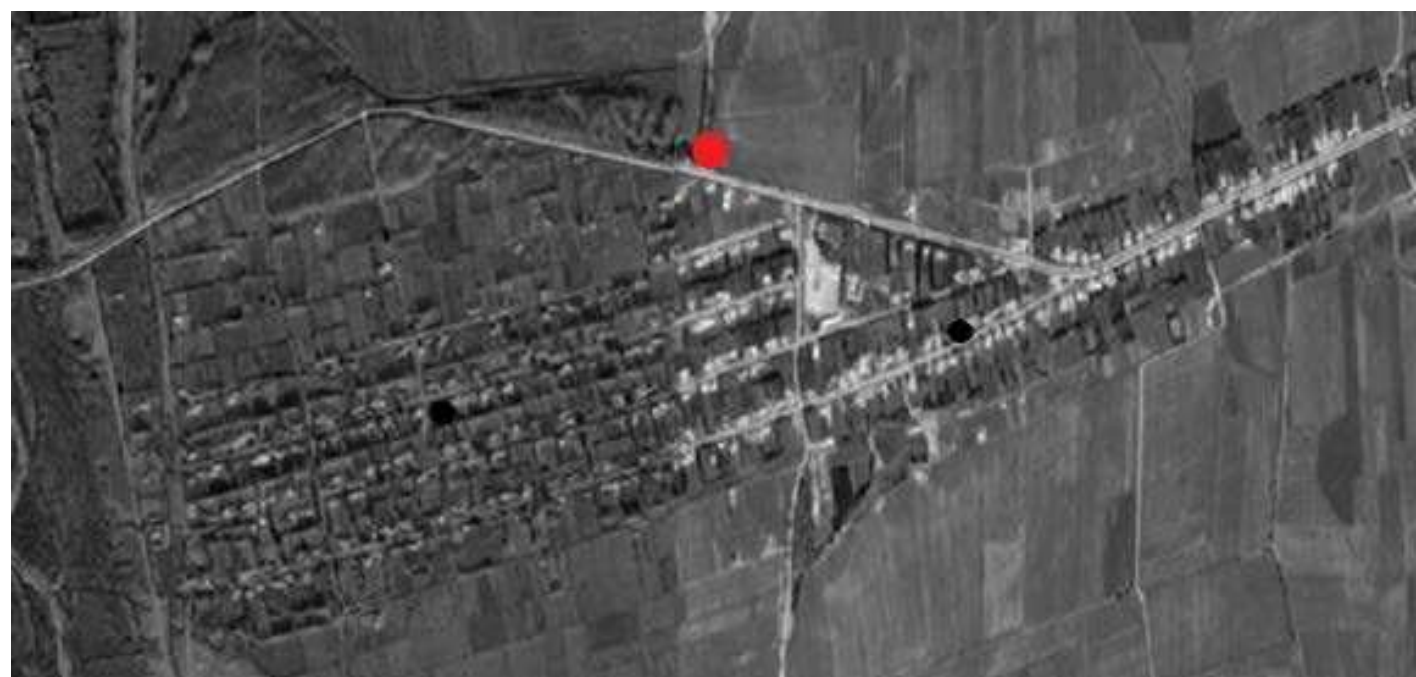

Source: GoogleMaps, survey results

22 Tilekeyev, K (2013). Productivity Implications of Participation in Export Activity: The case of Farmers in Talas Oblast of. University of Central Asia, Working Paper No. 17.

23 Tilekeyev, K. (2014) Rural Poverty Determinants in the Remote Rural Areas of Kyrgyzstan: A Production Efficiency Impact on the Poverty Level of a Rural Household. (Monograph), Peter Lang, Frankfurt am Main, 2014. XII, 234 pp. ISBN 978-3-631-65093-6 hb.

24 Black spots - farmers - bean shoppers, red dots - farmer-purveyor. 
Households involved in bean cultivation since 2011 were selected from this sample in the Kara-Buura and Bakai-Ata districts, of which 40 households producing beans were selected. This enabled the performance of farms engaged in bean production for several years to be compared. At the same time, a survey among the farmers-bean producers and farmers-purveyors was conducted in 10 villages of the Kara-Buura and Bakai-Ata districts (see Table 7). It should be noted that the sample of the covered farmers-bean producers is not representative, as there was no opportunity to interview the whole panel of 2011. However, in order to understand the processes of the beans value chain, this sample is sufficient.

\subsection{Farmers-beans producers}

As was already mentioned above, most beans, as well as all agricultural products in the region, are produced by small household farms, who are the first link in the beans production value chain.

This section looks at two groups of farmers: (1) farmers producing beans and other agricultural products and (2) farmers - purveyors. With regard to general issues, the data will be provided in general for all farmers, with the exception of information on the purchase and resale of beans, as well as on data on production characteristics.

\subsubsection{Agrotechnical and phytosanitary practice and issues}

Beans are planted during May starting from the end of April. Farmers either select seeds of beans for future harvest out of their yield or buy them at the market depending on the purchase price. Two-thirds of the farmers use seeds of their own production. The farmers experiencing yields decline buy seeds from farmers who are acquaintances or from those at the market.

In the meantime, in accordance with Resolution No. 376 of the Government of the Kyrgyz Republic dated 26.06.2013, there is one certified producer in the region - seed farm "Babyr Ata Mol Tushum", which intends to provide farmers with certified seeds. The interviewed farmers have not heardabout this. It was noted that there were no certified seeds in the open market. Information on seed provision is generally assessed by farmers as unsatisfactory and not credible.

Crop rotation is used by farmers in case of urgent need - beans are uninterruptedly sown for several years until the soil is completely depleted. A 1-2 year break is made in case of a sharp decline in yields to less than 1 ton/ha. Crops that replace beans are wheat, barley and lucerne. The respondents noted that the weather was favourable during the 2016 agricultural season - a warm season with abundant rainfall and sufficient irrigation water, without strong winds and hail.

The farmers noted two types of problems: (1) damage and weakening of plants caused by poor farming techniques and adverse weather conditions, and (2) diseases and pests. Diseases can be caused by wrong sowing (sowing too early/too late) that may coincide with rain that forms a crust on the soil surface and prevents shoots from breaking through. Other factors are as follows:

- abundant weeds that require weeding,

- untimely irrigation,

- extremely hot weather and strong wind during beans flowering period.

Farmers noted insects that attack beans, the names of which they did not know. They describe them as yellow-brown and small black insects that appear during the flowering period (most likely they are talking about the Lima-bean pod borer ${ }^{25}$ and sprout $f^{26}{ }^{26}$ ). In addition, there is

25 Latin name - Etiella zenckeneila, English name - Lima-bean pod borer

26 English name-Delia platura 
evidence of a disease that leads to leaves yellowing and cobwebs in the early vegetation period, which results in yield loss (symptoms are similar to viral mosaic ${ }^{27}$ ). The farmers say that diseases and pests were observed in 2015, but in 2016 the situation was more favourable.

Information on pest and disease control at the farmer level is extremely limited. The sources of advice and suggestions on plant diseases for farmers include staff at agro-veterinary pharmacies selling plant protection products, as well as farmers who are familiar with such topics. According to farmers, staff of agro-veterinary pharmacies are quite competent in plant diseases and pests. In general, farmers do not perceive this topic as a problem. Important factors for farmers include proper agrotechnical aspects - the timely sowing of beans, weeding and timely irrigation.

At the same time, there are no specialized communication channels to advise farmers on phytosanitary issues, agronomy and ways to increase labor productivity, as well as to improve soil fertility. Most farmers are very interested in this information. Farmers asked that they be provided with advice and information sources regarding consultations by telephone, mobile application development, and the distribution and sale of training manuals.

From the point of view of dealers - wholesalers, the impact of diseases and pests on crops is insignificant. At the same time, they note that the impact of weather conditions - temperature and precipitation - is of great importance and can provoke diseases or the spread of pests. They also believe that timely irrigation and weed control are determining factors in beans yield. According to farmers, the size of beans to a great extent depends on timely irrigation, as well as the application of fertilizers in the case of soil depletion.

The main variety of beans, which is popular among farmers, is white kidney bean ${ }^{28}$ (see Table 9). At least $70 \%$ of all beans cultivated in the region is white kidney bean. Some farmers have attempted to grow new kinds of beans, which are more in-demand and thus productive, such as "Navy beans" 29 . Farmers also mentioned their attempts to grow garbanzo ${ }^{30}$ in a neighbouring area a few years ago. Their attempts failed and pests destroyed a major part of this crop. Farmers say that garbanzo is a capricious and weak crop. None of the interviewed farmers have tried to cultivate other varieties of leguminous crops.

According to the majority of farmers, the main factors affecting crop yield are good seeds, the use of fertilizers (both mineral and organic), as well as regular irrigation. Many farmers are aware of the need to comply with crop rotation to maintain good yields, but they do not do so in practice. Factors of bean productivity include proper agrotechnical aspects - compliance with sowing timing, weeding and the use of plant protection means.

\footnotetext{
$27 \quad$ English name - Bean yellow mosaic virus (BYMV) or Bean common mosaic virus (BCMV)

28 International trade name - White kidney bean

29 International trade name - Navy beans

30 Kyrgyz name - Nokot, Latin name - Cicer arietinum
} 
Table 9. Classification of common varieties of kidney beans (Phaseolus vulgaris) in Kyrgyzstan and international varieties ${ }^{31}$

\begin{tabular}{|c|c|c|}
\hline $\begin{array}{c}\text { Local names of bean } \\
\text { varieties }\end{array}$ & International trade name & Bean photos \\
\hline Riabaya (Рябая) & Cranberry bean & \\
\hline Lopatka (Лопатка) & White kidney bean & \\
\hline Yubka (Юбка) & Rounded Caparron & \\
\hline Bokser (Боксер) & $\begin{array}{l}\text { Borlotto or } \\
\text { Red Pinto }\end{array}$ & \\
\hline Tomatnaya (Томатная) & Small red & \\
\hline Gorokh (Горох) & Navy beans & \\
\hline
\end{tabular}

Source: survey data

31 This classification is provided by an expert on bean diseases S. Khegay, staff of the Academy of Sciences of the Kyrgyz Republic. 


\subsubsection{Agricultural production}

Farmers' main productive asset is agricultural land. Their own irrigated arable land (66\% of all agricultural land) increased by 3.6\% between 2011 and 2017. In the composition of the land, there were rainfed lands -5.2 hectares, the area of declared household plots increased slightly (from 7 to 9.2), and the area of gardens grew from 0.6 hectares to 4.8 hectares. It is noteworthy that the area of leased land has significantly increased - from 13.9 hectares to 22 hectares. Meanwhile, all leased arable land is irrigated.

Table 10. Availability and structure of farmers' land plots in the sample, 2011 and 2016

\begin{tabular}{|c|c|c|c|c|c|c|c|}
\hline \multirow[t]{2}{*}{ № } & \multirow{2}{*}{$\begin{array}{l}\text { Types of } \\
\text { land plots }\end{array}$} & \multicolumn{3}{|c|}{2016} & \multicolumn{3}{|c|}{2011} \\
\hline & & $\begin{array}{l}\text { Number of } \\
\text { farmers }\end{array}$ & $\begin{array}{l}\text { Land in } \\
\text { total, ha }\end{array}$ & $\begin{array}{l}\text { Average } \\
\text { plot }^{31} \text {, ha }\end{array}$ & $\begin{array}{l}\text { Number of } \\
\text { farmers }\end{array}$ & $\begin{array}{l}\text { Land in } \\
\text { total, ha }\end{array}$ & $\begin{array}{l}\text { Average } \\
\text { plot, ha }\end{array}$ \\
\hline 1 & $\begin{array}{c}\text { Irrigated } \\
\text { arable lands }\end{array}$ & 40 & 88.3 & 2.2 & 40 & 85.2 & 2.1 \\
\hline 2 & $\begin{array}{l}\text { Rainfed } \\
\text { lands }\end{array}$ & 5 & 5.2 & 1.0 & 0 & 0.0 & 0.0 \\
\hline 3 & Hayfields & 4 & 3.8 & 0.9 & 0 & 0.0 & 0.0 \\
\hline 4 & $\begin{array}{l}\text { Household } \\
\text { plots }\end{array}$ & 40 & 9.2 & 0.23 & 40 & 7.0 & 0.2 \\
\hline 5 & Gardens & 9 & 4.8 & 0.5 & 1 & 0.6 & 0.6 \\
\hline \multirow[t]{2}{*}{6} & $\begin{array}{c}\text { Rented } \\
\text { arable land }\end{array}$ & 9 & 22.0 & 2.4 & 8 & 13.9 & 1.7 \\
\hline & $\begin{array}{l}\text { Total } \\
\text { agricultural } \\
\text { lands }\end{array}$ & & 133.2 & & & 106.7 & \\
\hline
\end{tabular}

The average cost of renting a land plot since 2016 has been 7500 KGS/ha per year. The rental cost in 2011 was slightly lower - 7300 KGS/ha per year. The range of prices for land rent differs greatly from 1000 to 10000 KGS in 2001, and in the range of 3000 to 14000 KGS in 2016. In general, growth of land use by $30 \%$ is due to the growth of leased land. In the meantime, the share of land used for agricultural crops declined slightly: in 2011, 1.1\% of agricultural land was not used, while in 2016 this share increased to 5.9\%. It is possible that farmers might set aside part of the land in the current year and compensate for the lack of that amount of land by renting additional arable land. In general, the amount of agricultural land used based on the sample data increased by $24.8 \%$ over 5 years and composed 3.3 ha per household instead of 2 ha in 2011.

32 An average plot is given for farmers with this type of land. 
Table 11. Basic indicators of main crops production in 2011 and 2016

\begin{tabular}{|c|c|c|c|c|c|c|}
\hline \multirow{2}{*}{ Crop name } & \multicolumn{2}{|c|}{ Size, ha } & \multicolumn{2}{c|}{ Gross yield, tons } & \multicolumn{2}{c|}{ Productivity, t/ha } \\
\cline { 2 - 7 } & 2016 & 2011 & 2016 & 2011 & 2016 & 2011 \\
\hline Beans & 94 & 80 & 157.2 & 117.4 & 1.7 & 1.5 \\
\hline Grains & 4 & 7 & 7.2 & 11.5 & 1.8 & 1.7 \\
\hline Perennial grasses & 15 & 9 & 73.0 & 26.9 & 4.7 & 3.1 \\
\hline Potatoes & 2 & 1 & 12.9 & 8.5 & 7.4 & 6.6 \\
\hline
\end{tabular}

Source: survey data

Table 12. Main indicators and the role of beans on crop sale by bean farmers in 2011 and 2016.

\begin{tabular}{|c|c|c|c|c|c|c|}
\hline \multirow{3}{*}{ Indicators } & \multicolumn{3}{|c|}{2016} & \multicolumn{3}{|c|}{2011} \\
\hline & \multirow[b]{2}{*}{ Total } & \multicolumn{2}{|c|}{ per 1 farmer } & \multirow[b]{2}{*}{ Total } & \multicolumn{2}{|c|}{ per 1 farmer } \\
\hline & & KGS & $\begin{array}{c}\text { US } \\
\text { dollars }^{32}\end{array}$ & & KGS & $\begin{array}{c}\text { US } \\
\text { dollars }\end{array}$ \\
\hline $\begin{array}{c}\text { Sale of crop products, } \\
\text { KGS }\end{array}$ & $10,615,455$ & 265,386 & 3,796 & $3,466,100$ & 86,653 & 1,878 \\
\hline Sale of beans, KGS & $9,822,330$ & 245,558 & 3,512 & $3,172,600$ & 79,315 & 1,719 \\
\hline $\begin{array}{l}\text { Sale of beans, } \% \text { of } \\
\text { crop production (by } \\
\text { weight) }\end{array}$ & $94 \%$ & & & $93 \%$ & & \\
\hline $\begin{array}{l}\text { Share of beans in the } \\
\text { total sale of crops }\end{array}$ & $93 \%$ & & & $92 \%$ & & \\
\hline Sale of beans, kg & 147,770 & & & 109,400 & & \\
\hline $\begin{array}{c}\text { Cost per } 1 \mathrm{~kg} \text { of beans, } \\
\mathrm{KGS} / \mathrm{kg}\end{array}$ & 66.5 & & & 29.0 & & \\
\hline $\begin{array}{c}\text { Cost per } 1 \mathrm{~kg} \text { of beans, } \\
\text { USD } / \mathrm{kg}\end{array}$ & 0.95 & & & 0.63 & & \\
\hline
\end{tabular}

Source: survey data, own calculations

Bean is the main crop among other grown crops. It occupied $75 \%$ of all available land in 2011 and $70 \%$ in 2016 . Among the major crops, it is necessary to note the growth of perennial grass lands, from $8.4 \%$ in 2011 to $11.2 \%$ in 2016 . Declared yields of major crops were slightly higher in 2016. It should be noted that the respondents noted weather and climate conditions in 2016 as favourable in comparison with 2015.

The role of beans in the sale of plant products is predominant - 92-93\% of total farm sales. It should be noted that comparing 2016 to 2011, growth is extremely high - sales have grown almost 3.5 times (see Table 3.6.). The main reasons for growth are: a change in the KGS/USD exchange rate over the reporting period (an increase by $52 \%$ ), an increase in procurement prices

33 According to the National Statistical Committee the average annual KGS/USD exchange rate in 2016 was $70.09 \mathrm{KGS} / \mathrm{USD}$.

34 According to the National Statistical Committee the average annual KGS/USD exchange rate in 2011 was 46.14 KGS/USD. 
for beans (more than twice), and an increase in physical sales volume (by 35\%) due to the growth of arable land and some growth in beans yield. It should be noted that even when considering the sales of plant products by farmers in foreign currency (in US dollars), sales growth has more than doubled.

Table 13. Ownership of livestock by farmers in 2011 and 2016, animal heads in the sample

\begin{tabular}{|c|c|c|c|c|}
\hline № & & 2016 & 2011 & growth rate, \% \\
\hline 1 & Cattle & 72 & 67 & 107 \\
\hline 2 & Sheep & 596 & 445 & 134 \\
\hline 3 & Horses & 27 & 23 & 117 \\
\hline 4 & Poultry & 239 & 174 & 137 \\
\hline 5 & Goats & 17 & 10 & 170 \\
\hline \multicolumn{4}{|r}{} \\
\hline
\end{tabular}

In addition to plant production, farmers also have livestock, and the amount of such households has increased. If in 2011 65\% of sample farmers kept farm animals, in 2016 their number increased to $85 \%$. The main type of livestock is cattle - the proportion of households raising cows increased from 50\% to 63\% between 2011 and 2016. The second most popular species among household animals is sheep. The share of households raising sheep increased from 35\% to 60\%. The share of farmers breeding horses doubled from 15\% to 30\%. An increase in the number of farmers growing beans and having farm animals led to a certain reduction in the number of the main kinds of livestock per household (see Table 13). Given that for the rural population livestock is a way to form both fixed and working capital, this trend indicates a growing capitalization of the agricultural sector, specializing in beans.

\section{Agrotechnics of bean cultivation}

Bean is a warm-season crop, sensitive to frost. A long-term decrease in temperature adversely affects sprout, while high temperatures and dry winds during flowering negatively affect beans yield, and a lack of warmth and rainy weather during flowering cause blossom fading ${ }^{35}$.

The climate in the Talas region, being dry and windless, is the most suitable for growing beans. Representatives of the Seed Association of Kyrgyzstan also consider the conditions in the Kochkor district of the Naryn region and the Issyk-Kul region as favourable, but according to the entrepreneurs' feedback, the Issyk-Kul region is cooler and requires earlier ripening varieties than those cultivated in Talas.

Most of the operations in the production of beans are carried out mechanically - soil smoothing, ploughing, planting and cultivation of crops. However, there is one important operation that is done manually - harvesting. The plant is cut with a sickle, a scythe and then remains on the field for 10-15 days until it dries. Farmers do this themselves, and also by hiring workers. When dried, plants are manually stacked across the field, before a combine is brought to thresh and shell the beans. Beans are packed in bags and transported from the field home. 


\section{Cost of production of beans}

In addition to mechanized work and harvesting, growing beans includes a number of production costs, which are provided in detail in Table 14 and 15 for 2011 and 2016.

Table 14. Main production costs of the farmers-bean producers in 2011

\begin{tabular}{|c|c|c|c|c|c|c|c|}
\hline & \multicolumn{7}{|c|}{2011} \\
\hline & \multirow{2}{*}{\multicolumn{2}{|c|}{ Total sample costs }} & \multicolumn{4}{|c|}{ including } & \multirow{3}{*}{$\%$} \\
\hline & & & \multicolumn{2}{|c|}{ Per 1 ha } & \multicolumn{2}{|c|}{ Per $1 \mathrm{~kg}$} & \\
\hline & KGS & USD & KGS & USD & KGS & USD & \\
\hline Seeds & 31,750 & 688 & 397 & 8.6 & 0.3 & 0.007 & 3 \\
\hline Mineral fertilizers & 184,950 & 4,008 & 2310 & 50.0 & 1.6 & 0.035 & 17 \\
\hline Herbicides, pesticides & 6,250 & 135 & 78 & 1.7 & 0.1 & 0.002 & 1 \\
\hline Organic fertilizers & 1,500 & 33 & 19 & 0.4 & 0.0 & 0 & 0 \\
\hline Packaging materials & 19,910 & 432 & 249 & 5.4 & 0.2 & 0.004 & 2 \\
\hline Harvest transportation & 49,200 & 1,066 & 615 & 13.3 & 0.4 & 0.009 & 5 \\
\hline \multicolumn{8}{|l|}{ Mechanized work } \\
\hline Soil smoothing & 36,675 & 795 & 458 & 9.9 & 0.3 & 0.007 & 3 \\
\hline Plowing & 152,533 & 3,306 & 1,905 & 41.3 & 1.3 & 0.028 & 14 \\
\hline Planting & 73,455 & 1,592 & 918 & 19.9 & 0.6 & 0.013 & 7 \\
\hline Cultivation & 47,928 & 1,039 & 599 & 13.0 & 0.4 & 0.009 & 4 \\
\hline Combine bean cleaning & 170,230 & 3,689 & 2127 & 46.1 & 1.5 & 0.032 & 16 \\
\hline Combine fuel & 35,310 & 765 & 441 & 9.6 & 0.3 & 0.007 & 3 \\
\hline Manual harvesting & 108,350 & 2,348 & 1,354 & 29.3 & 0.9 & 0.02 & 10 \\
\hline $\begin{array}{c}\text { Land tax } \\
\text { (\% of share in crops) }\end{array}$ & 26,066 & 565 & 326 & 7.1 & 0.2 & 0.004 & 2 \\
\hline $\begin{array}{c}\text { Social Fund } \\
\text { (\% of share in crops) }\end{array}$ & 22,447 & 487 & 280 & 6.1 & 0.2 & 0.004 & 2 \\
\hline $\begin{array}{c}\text { Irrigation } \\
\text { (\% of share in crops) }\end{array}$ & 27,985 & 607 & 350 & 7.6 & 0.2 & 0.004 & 3 \\
\hline Land rent & 94,000 & 2,037 & 1,174 & 25.4 & 0.8 & 0.017 & 9 \\
\hline Total & $1,088,538$ & 23,592 & 13,598 & 294.7 & 9.3 & 0.202 & 100 \\
\hline
\end{tabular}

Sources: survey data, own calculations 
Table 15. Main production costs of the farmers-bean producers in 2016

\begin{tabular}{|c|c|c|c|c|c|c|c|}
\hline & \multicolumn{7}{|c|}{2016} \\
\hline & \multirow{2}{*}{\multicolumn{2}{|c|}{ Total sample costs }} & \multicolumn{4}{|c|}{ including } & \multirow{3}{*}{$\%$} \\
\hline & & & \multicolumn{2}{|c|}{ Per 1 ha } & \multicolumn{2}{|c|}{ Per 1 kg } & \\
\hline & KGS & USD & KGS & USD & KGS & USD & \\
\hline Seeds & 162,800 & 2,323 & 1,724 & 24.6 & 1.0 & 0.015 & 7 \\
\hline Mineral fertilizers & 404,550 & 5,772 & 4,285 & 61.1 & 2.6 & 0.037 & 16 \\
\hline Herbicides, pesticides & 95,140 & 1,357 & 1,008 & 14.4 & 0.6 & 0.009 & 4 \\
\hline Organic fertilizers & 17,800 & 254 & 189 & 2.7 & 0.1 & 0.001 & 1 \\
\hline Packaging materials & 39,080 & 558 & 414 & 5.9 & 0.2 & 0.003 & 2 \\
\hline Harvest transportation & 60,950 & 870 & 646 & 9.2 & 0.4 & 0.006 & 2 \\
\hline \multicolumn{8}{|l|}{ Mechanized work } \\
\hline Soil smoothing & 80,560 & 1,149 & 853 & 12.2 & 0.5 & 0.007 & 3 \\
\hline Ploughing & 207,363 & 2,959 & 2,196 & 31.3 & 1.3 & 0.019 & 8 \\
\hline Planting & 90,921 & 1,297 & 963 & 13.7 & 0.6 & 0.009 & 4 \\
\hline Cultivation & 69,714 & 995 & 738 & 10.5 & 0.4 & 0.006 & 3 \\
\hline Combine bean cleaning & 498,418 & 7,111 & 5,279 & 75.3 & 3.2 & 0.046 & 20 \\
\hline Combine fuel & 19,440 & 277 & 206 & 3.0 & 0.1 & 0.001 & 1 \\
\hline Manual harvesting & 477,750 & 6,816 & 5,060 & 72.2 & 3.0 & 0.043 & 19 \\
\hline $\begin{array}{c}\text { Land tax ( } \% \text { of share in } \\
\text { crops) }\end{array}$ & 25,037 & 357 & 265 & 3.8 & 0.2 & 0.003 & 1 \\
\hline $\begin{array}{l}\text { Social Fund (\% of share } \\
\text { in crops) }\end{array}$ & 22,758 & 325 & 241 & 3.4 & 0.1 & 0.001 & 1 \\
\hline $\begin{array}{c}\text { Irrigation (\% of share in } \\
\text { crops) }\end{array}$ & 39,551 & 564 & 419 & 6.0 & 0.3 & 0.004 & 2 \\
\hline Land rent & 164,500 & 2,347 & 1,742 & 24.9 & 1.0 & 0.015 & 7 \\
\hline Total & $2,476,330$ & 35,331 & 26,227 & 374.2 & 15.8 & 0.225 & 100 \\
\hline
\end{tabular}

Sources: survey data, own calculations

In general, it should be noted that bean-farmers' production costs have grown significantly over the past six years - an increase of $70 \%$ per unit of produce. The main growth of expenses sources are seeds, manual harvesting, combine bean cleaning, expenses on organic and mineral fertilizers, and expenses on herbicides and pesticides. Other expenses have grown slightly or have slightly decreased.

The estimated gross margin of bean production at the farmer's level is quite high, even given that net profitability is obviously much lower (see note to Table 16). It should be noted that the favourable situation regarding purchase price in the second half of 2016 and early 2017 contributes to higher bean production appeal - the level of gross margin in 2016 was $100 \%$ higher than in 2011. Also, this calculation shows that profitability can drastically change for a farmer who has to operate in conditions of uncertainty over the beans price, depending on the timing of crop sale, taking into account both seasonal variability of the beans purchase price and changes occurring under the influence of fluctuations on international beans markets. 
Table 16. Estimated level of gross margin in production of beans at farmers level in 2016 and 2011

\begin{tabular}{|c|c|c|c|c|c|c|c|c|}
\hline & \multicolumn{4}{|c|}{2016} & \multicolumn{4}{|c|}{2011} \\
\hline & \multicolumn{2}{|c|}{ Total } & \multicolumn{2}{|c|}{ per kg of beans } & \multicolumn{2}{|c|}{ Total } & \multicolumn{2}{|c|}{ per kg of beans } \\
\hline & KGS & USD & KGS & USD & KGS & USD & KGS & USD \\
\hline $\begin{array}{c}\text { Production cost of } \\
\text { beans, KGS }\end{array}$ & $2,476,330$ & 35,331 & 15.8 & 0.22 & $1,088,538$ & 23,592 & 9.3 & 0.2 \\
\hline Sale of beans, KGS & $10,615,455$ & 151,455 & 66.5 & 0.95 & $3,466,100$ & 75,121 & 29 & 0.63 \\
\hline Gross margin, KGS & $8,139,125$ & 116,124 & 51 & 0.73 & $2,377,562$ & 51,529 & 20 & 0.43 \\
\hline $\begin{array}{l}\text { Gross margin, in } \\
\% \text { to the market } \\
\text { value }^{35}, \%\end{array}$ & \multicolumn{2}{|c|}{$329 \%$} & \multicolumn{2}{|c|}{$321 \%$} & \multicolumn{2}{|c|}{$218 \%$} & \multicolumn{2}{|c|}{$212 \%$} \\
\hline
\end{tabular}

Sources: survey data, own calculations

\subsubsection{Bean sales}

After harvesting, the procurement season begins. Most often farmers are not engaged in cleaning and sorting beans, rather they sell them in the form of "from the combine". Before, farmers cleaned beans themselves, whereas now they prefer to sell most of their harvest. According to them, the price decreases by 2-3 KGS/kg, given the culling. Bean buyers do the cleaning themselves. Some farmers, however, continue to clean beans manually, which slightly raises the selling price. Also, farmers clean beans manually if they want to keep larger bean seeds to plant the following year.

Bean buyers take beans either from the field - "from the combine", or directly from bean supply points. They take into account the following factors - the beans must be dry and clean, sorted in size, and not mixed with other sorts of bean. They accept any amount of beans, even 5 or 10 kilograms. When buying larger lots, one bag is randomly taken and dispersed to assess the presence of scruffs, which are small and damaged seeds. Furthermore, the proportion of waste is estimated, and the weight of the total lot is usually reduced from $2 \%$ to $6 \%$ for waste. Harvest waste, such as small or broken seeds, is ground in a mill and added to animal food or sold to buyers at a price of $10 \mathrm{KGS} / \mathrm{kg}$.

36 It should be noted that gross margin is not profitability of production in its pure form, since it includes two types of bean-farmer's income: cost of farmer's own labour for types of work that a farmer performed him/herself, as well as actual entrepreneurial income from efforts made to sell beans. Accordingly, the real profitability of beans is lower, level of which is difficult to determine, since it is preferable to calculate the alleged wages and non-monetary expenses on representative sample data. 
Figure 6. Average price for beans at the level of farmers-bean producers and farmers-purveyors in 2015-2017, KGS/kg

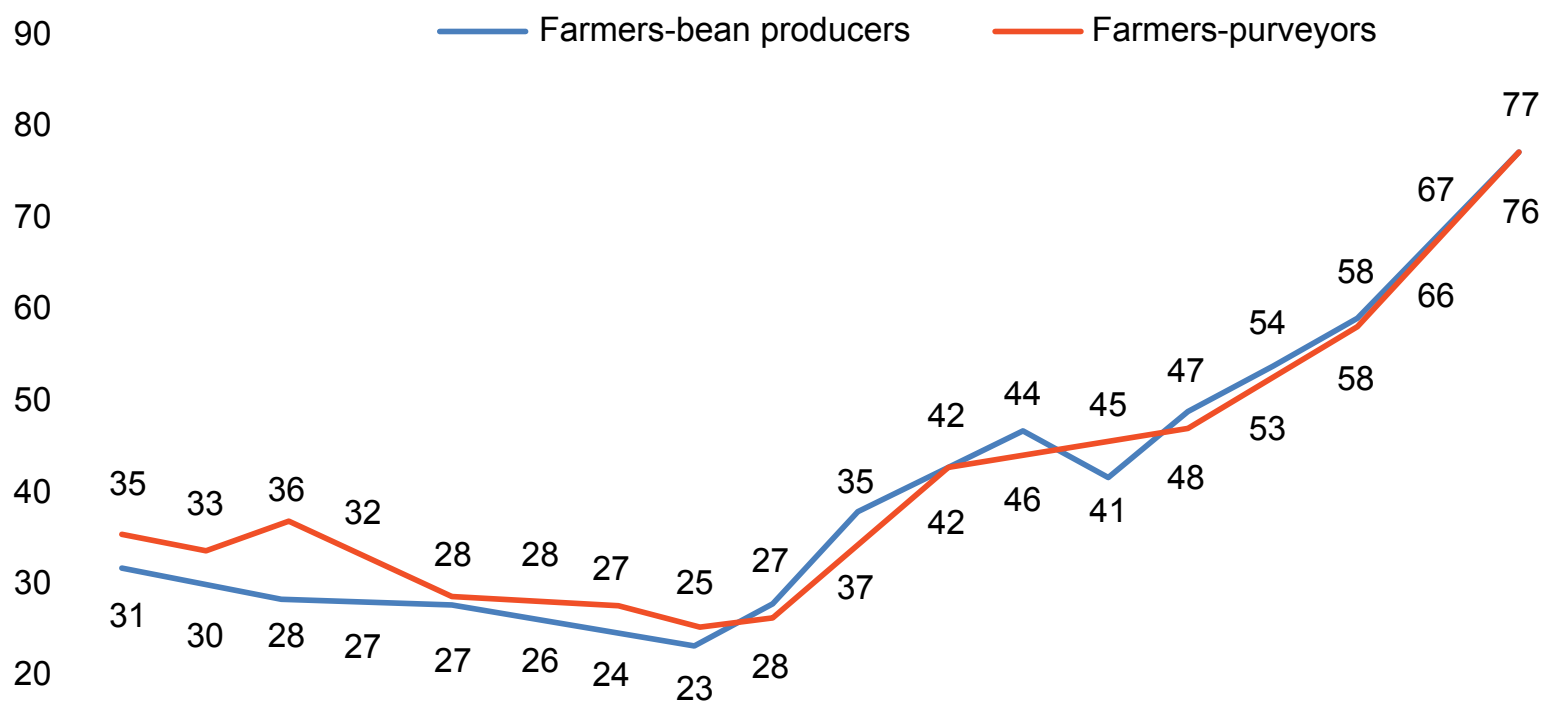

10

0

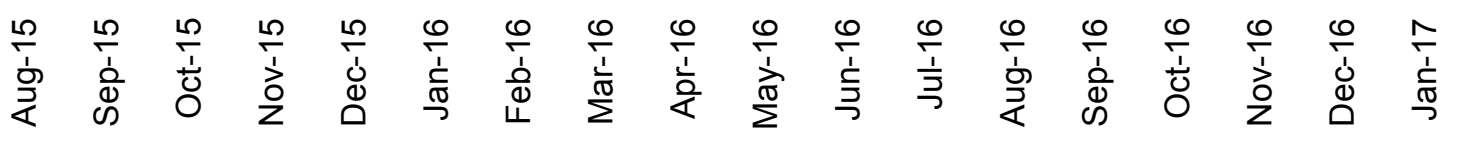

Source: own calculations

The price for beans in 2015-2016 fluctuated significantly with growth in the second half of 2016. In general, the price for beans in August 2016 - January 2017 exceeded the price in the same period of the previous year (August 2015 - July 2016) by 87\%. A favourable market situation contributes to the optimistic mood of farmers in 2016. As we see from the calculations of the previous section, the difference in profitability for farmers can fluctuate in a significant range.

Prices for separate bean sorts are exaggerated - the prices for the sorts "White Kidney" and "Navy beans" are almost identical and are 52 and 53 KGS / kg, respectively, while "Amerikanka" is 38 KGS.

The bean can be sold right after being harvested: $60 \%$ of crop is usually sold between September and the end of the year. The rest is sold in spring and summer the following year. Thus, farmers pursue two goals - to finance spring-field works and to increase their profits.

All farmers sell beans to resellers (farmers-purveyors and wholesalers). The price is determined at the village level, from buyers, acquaintances in neighbouring villages, as well as from other districts. The amount of beans that individual farmers sell is not enough to interest the following links in the supply chain - large wholesalers and exporters. Wholesalers' prices are not available to them. Also, farmers do not have any information on the conditions offered by wholesaler-exporters, quality requirements, documents, permits and laboratory tests.

State support in the form of preferential loans, seeds, fertilizers and fuel is not evident, according to the interviewed farmers. Many farmers have heard about such support, but information on how to get it and on what terms is unknown. Farmers believe that the state allocates insufficient 
funds for these purposes and information about such help does not reach farmers well enough. The entry of Kyrgyzstan into the EAEU went completely unnoticed by farmers - they know about the very fact of it, but can not say anything about any changes at their level. In their opinion, no significant changes have occurred as a result thereof.

\subsubsection{Farmers-purveyors}

Farmers-bean purveyors are first in the line of intermediaries. They are engaged in agricultural production, and also purchase beans to resell them later to exporting firms. Their niche is that they are geographically close to many small farmers and can supply beans in quantities suitable for wholesalers.

It is worth noting that farmers-purveyors are already aware of preferential loans and other help from the state (allocation of fuel, tractors, seeds). They also know about this kind of help being used by their acquaintances. They themselves usually do not need such help, as their own means is more often than not sufficient.

Farmers-purveyors cultivate beans, having different levels of experience: some 15-20 years, while others only a few years. Meanwhile, purchasing beans for all of these purveyors is a relatively new type of occupation, in which they have been engaged on average for the last 3-4 years. Beans stock gets ready starting from September till summer the next year. On average, a purveyor manages to buy and resell 200-250 tons of beans per season.

Farmers-purveyors usually work with several buyers, for whom they collect beans. With wholesalers, the price and terms are negotiated starting from August, a month before harvesting. Payment is in cash and farmers do not sale in debt. There are many agents in the market who buy beans. If a farmer wants to sell beans, a purveyor picks the beans directly from their home.

The main criteria for buying beans from a purveyor by a wholesaler-exporter are bean size, no impurities and that the beans must be dry. On average, lot sizes for sale can be different - from 20 to 80 tons. Buyers-wholesalers offer the same conditions as buyers to farmers. It is interesting to note that there is a requirement for packaging - sacks must be transparent, so that the beans can be seen as well as any impurities in them. Farmers-purveyors are supplied with bags by wholesalers. If the packaging (sack) is not transparent, then it must be opened, dispersed and re-packed in transparent bags.

Beans can be purchased both in the local village and in nearby ones. Buyers visit farmers one by one regularly and work with several dozen farmers every month. Some large-scale buyers expect farmers to arrive at their homes. The loading and unloading of beans is paid by the farmers-purveyors. One loading and unloading costs $10 \mathrm{KGS}$ per bag (50 kg).

Farmer-purveyors can arrange bean cleaning and sorting, as necessary (see Figure 8), but this is rarely required for selling to wholesalers. Manual bean cleaning costs 50-80 KGS per 1 sack (50 $\mathrm{kg}$ ). Wholesalers do not require any documents for beans from farmer-purveyors, nor do they provide any other additional services. Farmer-purveyors' margin is 3-5 KGS from $1 \mathrm{~kg}$ of beans and they have a lot of competitors - on average, 5-6 bean buyers work in each village. 
Figure 7. Examples of ready-packed beans (February 2017)

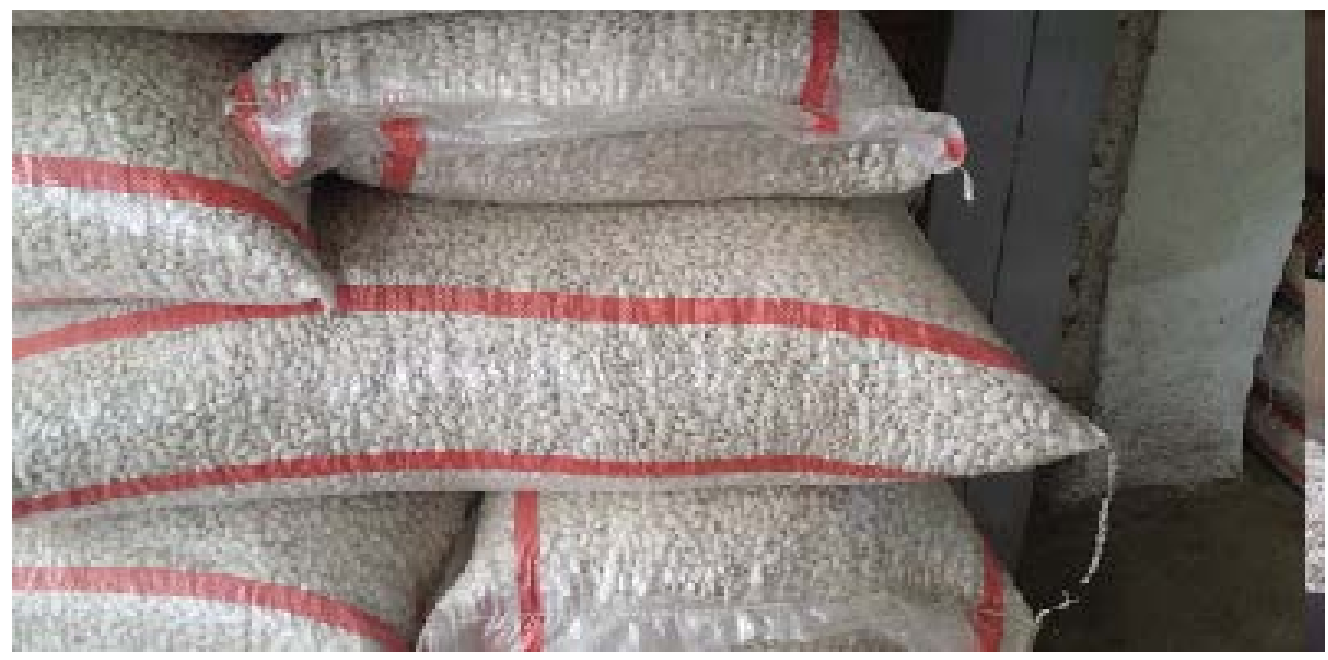

Source: survey data

Figure 8. Manual bean cleaning

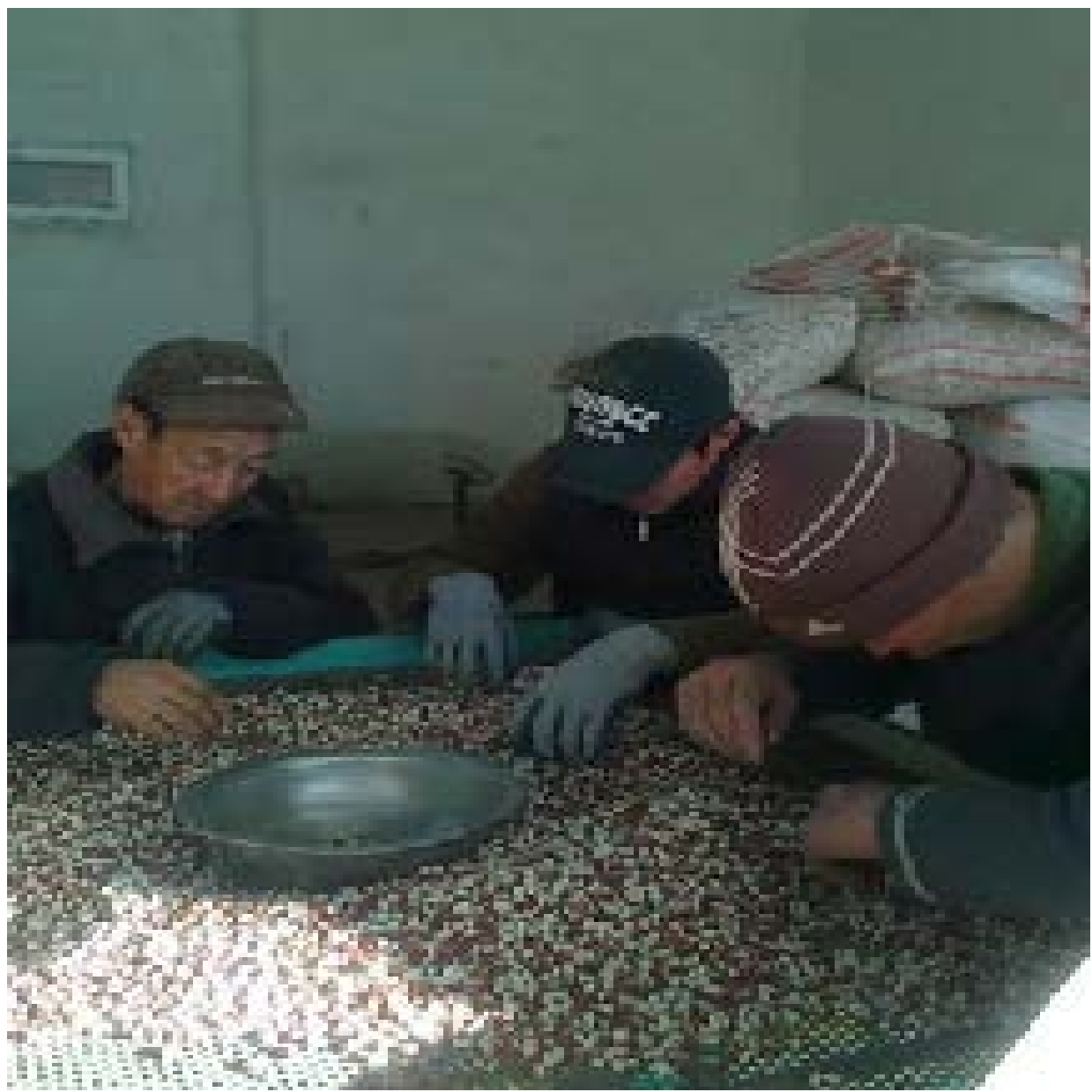

Source: www.akipress.org 
Farmers-purveyors do not know the price at which beans are sold by exporting firms. In general, they know that the ultimate markets are Turkey and Europe. They believe that the price for their services is fair. Each of them would increase the amount of purchased beans, but they do not have enough working capital. Therefore, many farmers-purveyors would like to attract investors.

\subsection{Commercial bean dealers-wholesalers}

In addition to farmers-purveyors, many wholesale dealers who operate in the bean market are engaged in this business on a commercial basis, without being directly involved in agricultural activities. Wholesalers of beans work only based on the patent with the main activity focused on beans purchase and sale. For all of them beans purchase and resale has been their main business for the past 10-15 years. Most of the wholesalers hire 3 to 10 employees. The annual gross margin is on average 2-6 million KGS. Wholesalers use their own funds and those of investors. Most wholesalers intend to increase their turnover in 2017, but failed to outline their long-term prospects.

The main asset for wholesalers is the warehouse, the size of which varies from 50 to $1,500 \mathrm{~m} 2$. Another important asset is vehicles. Each wholesaler has $-2-5$ vehicles, including passenger vehicles, trucks and minibuses. Large warehouses of 1,000 $\mathrm{m} 2$ usually have bean cleaning and sorting equipment; whereas owners of small warehouses have no high-capacity equipment.

The annual volume of bean purchase per 1 wholesaler varies from 1,000 to 10,000 tons, with $3,000-3,500$ tons on average. Wholesalers normally work in 2-3 districts covering 10 to 50 villages (20 villages on average). During one season they cover on average 1,000-1,200 farmers, including farmers-purveyors. Each village has 1-2 bean collecting points, represented by either a farmer-purveyor or agent of a wholesaler (usually a relative).

Many wholesalers deal with relatives' yield, which they take with a minimum price guarantee. At the beginning of the season, following bean harvesting, the wholesaler agrees with their relatives that they will provide them with their harvest for further resale. Wholesalers assume obligations at the minimum beans price, which was $35 \mathrm{KGS}$ per $1 \mathrm{~kg}$ of beans in autumn 2016. Later, during the bean sale season, relatives may charge a wholesaler at the current market price, but not lower than the agreed minimum price.

Thus, payment terms have elements of future transactions - minimum price and settlement at the market price within several months. The benefit for farmers-producers is the guarantee of a minimum price, while the benefit for a wholesaler is an increase in working capital.

The initial price for the current year yield is formed during August-September. Payment is made by cash at the time of the beans purchase. Some wholesalers may take beans with deferred payment for a maximum of one week. In addition, wholesalers might be given beans in debt by relatives, with a view to price increase on beans. Bean is purchased with regard to sort, size of bean seeds, pureness (absence of impurity) of bean seeds colour and its dryness. Mixed sorting (mixing several varieties in one batch) reduces the purchase price significantly. Buyers (exporting firms) provide new packaging - transparent plastic bags. Wholesalers do not prepare document for exporting, and provide a patent if required.

Beans consolidation requires considerable loading and unloading. Wholesalers hire loaders at market rates: $5 \mathrm{KGS}$ for loading/unloading of 1 sack (50 kg). If a loader is hired for a light day, he 
gets $500-1,000 \mathrm{KGS}$ (500 KGS for work from 9 am to $6 \mathrm{pm}$ with one hot meal, and 1,000 KGS for work from 9 am to $10-11$ pm with 2 meals a day).

The average bulk of beans purchased by exporting firms varies from 22 to 66 tons (1 to 3 trucks). This quantity depends on the average batch of goods for export of 22 tons per 1 truck (TIR Carnet) ${ }^{37}$. Loading of goods on the clients' vehicle is included in the sale price of the beans.Seeds are cleaned using cleaning equipment to discard broken or small seeds, impurities and for sizebased bean separation. Cleaning costs 80 to 100 KGS per 1 sack (50 kg).

Some wholesalers used to prepare documents for each bulk, but now exporting firms prepare such documents themselves. According to wholesalers, a standard package of documents includes: cargo customs declaration, supply contract, certificate of origin, certificate of conformity, phytosanitary certificate when exporting goods to Europe. When exporting to EAEU countries supply contract, invoice, phytosanitary certificate and laboratory conclusion (certificate that the product is not infected with spongiform encephalopathy - see Annex 2) are necessary. The laboratory conclusion is made in Almaty and takes one week for a batch of goods. On average, official payments for 1 batch of goods ( 1 truck - 22 tons) equal 5,000 KGS, while there are also unofficial payments in the amount of 1,000 to 2,000 KGS for a package of documents.

Competition for buying beans is strong with 5 to 15 purchasers in each village, both farmers-purveyors and wholesalers. This aligns the purchase price. Wholesalers' margin (net margin) from the beans is $2-3 \mathrm{KGS}$ per $1 \mathrm{~kg}$.

Wholesalers have some idea of the final destination of bean exports. This is usually the countries of South-Eastern Europe, Turkey, and Russia. Some have more detailed information on exports to other countries - Georgia, Iran, Ukraine (Ministry of Defence). They do not know the ultimate exporting price. According to the wholesalers, bean prices are coordinated among exporting firms (primarily firms from Turkey); the price difference within the region is usually insignificant of 1-2 KGS per kilogram, which can be due to transport and logistics costs.

Wholesalers usually do not attempt to export the beans themselves, and their clients are bean exporters. Some have tried to attract foreign investors and to organize export, but have failed.

Wholesalers have been unaware of any barriers to the exporting of beans over the past few years; among the operational problems they have mentioned delays during customs clearance, when they refuse to make unofficial payments. Wholesalers mentioned the positive impact of Kyrgyzstan's entry into the EAEU and provided some facts related to the increased supplies of beans to Russia and Kazakhstan. They believe that this positively affects purchase prices. None of the respondent noted any efforts of the state to support bean export. They mentioned the need to build a laboratory in Talas for testing bean samples when exporting to the EAEU for obtaining a prescribed certificate.

The average price for beans at wholesale outlets for the period of time under consideration was reported to be slightly higher than the farm gate price, while the reverse relationship between wholesale and farm gate prices is also possible.

37 Carnet TIR (TIR Carnet, international road transportation) is a customs transit document, which entitles to transport goods across borders of states in car bodies or containers sealed by customs, with simplification of customs procedures. For more information see https://www.unece.org/fileadmin/DAM/tir/handbook/TIRConventionENFRRU.pdf and http://www.unece.org/tir/system/tir-system-countries.html 
The differences between these prices may be due to the impact of single transactions (deals) in the formation of specific orders for the supply of beans under some contracts. This is evidenced by the deviation amount - if the price is lower than the farmers' price, it is usually 1-2 KGS/1 kg lower, and if higher, in some months deviation is 5 - $8 \mathrm{KGS} / 1 \mathrm{~kg}$ (three months in 2016). This may indicate that wholesalers wait for extremely high demand in order to increase profit in speculative moments.

Many wholesalers mentioned that they would like to attract investors to increase turnover. This is due to the favourable price of beans and an increasing demand for beans in the past few months of 2016. In general, the price fluctuations at all levels of the value chain are well correlated.

Figure 9. Beans prices at wholesalers level in 2015-2016, KGS/kg

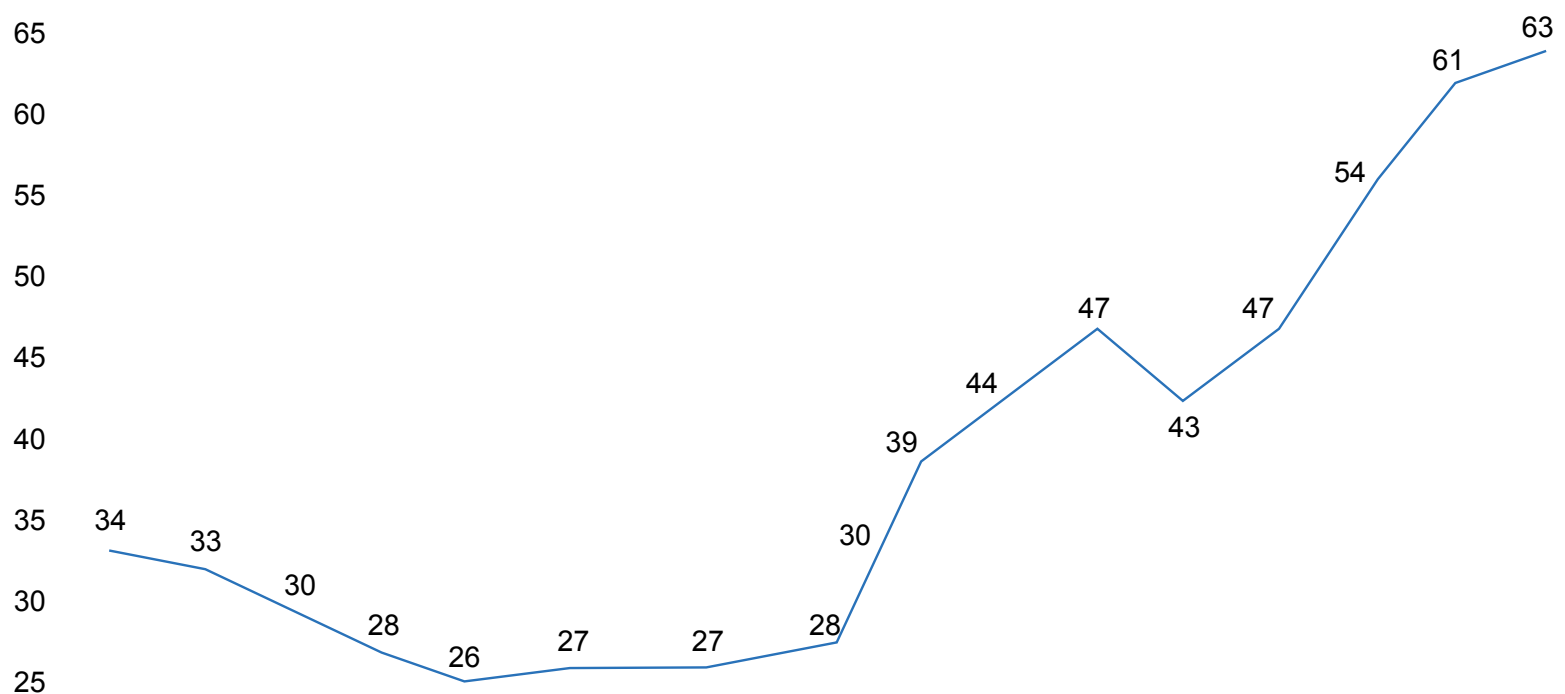

20

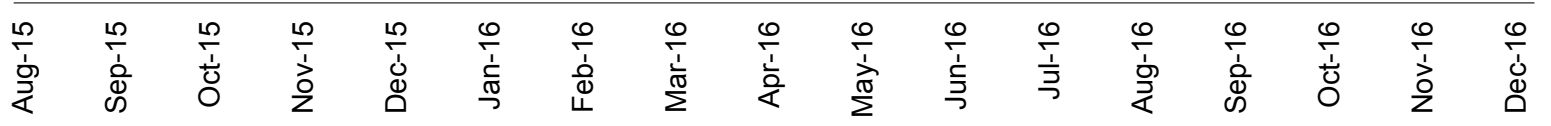

Source: authors' calculations

\subsection{Bean post-harvesting - bean cleaning workshops}

Beans are still processed (cleaned, sorted and packed) manually; however, gradually, in the last few years, the post-harvest processing of beans has become increasingly mechanized, with more automation. Bean cleaning workshops are registered as a business (limited liability companies or individual entrepreneurs) and all have permanent staff ranging from 5 to 30 people depending on the season. Each workshop has a warehouse $(100-8,000 \mathrm{~m} 2)$, trucks and equipment for cleaning and sorting beans. Equipment may differ depending on the workshop size. There are two types of beans cleaning workshops - small and large ones. 


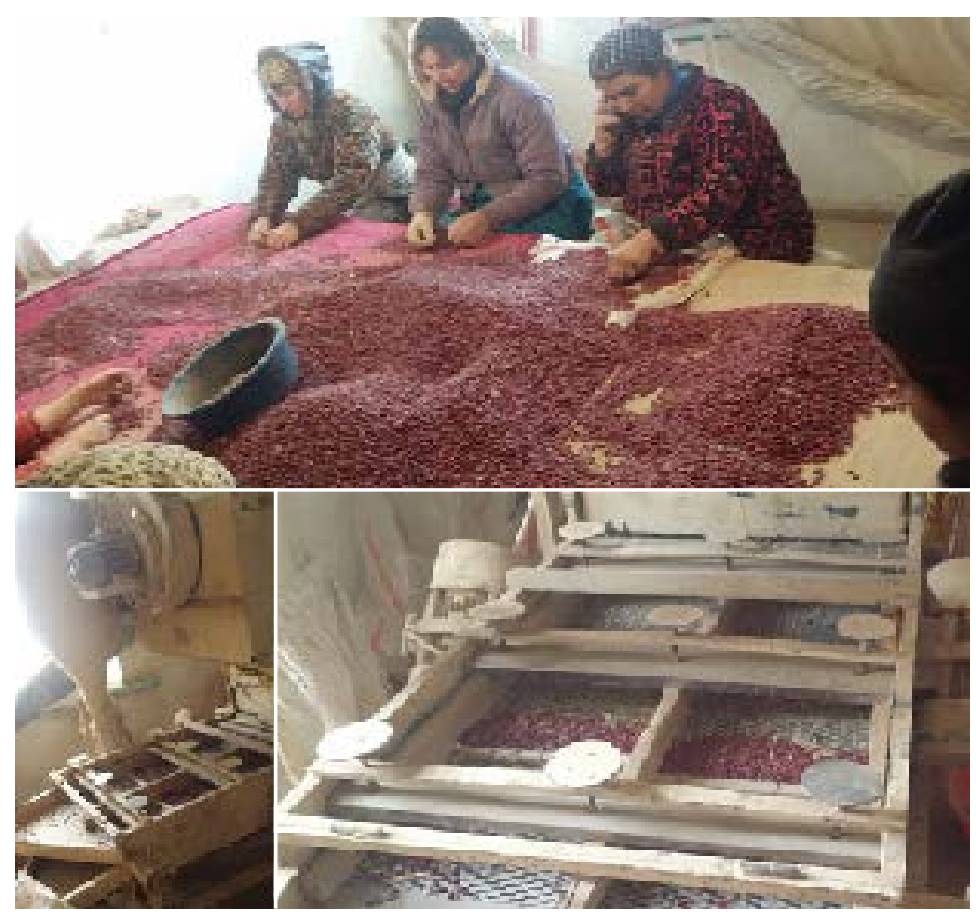

Source: data of the survey

Small workshops usually have a device for the initial cleaning of beans from stones, waste and broken beans - using a sieve. This device is quite primitive and does not allow for comprehensive cleaning; therefore, careful manual cleaning is needed. Manual cleaning allows selecting beans of other sorts, broken beans, beans of differing color and those affected by pests. Small workshop capacity is about 1 ton per day. Most work is done by women - manual cleaning, while men work as loaders. Standard payment is $2 \mathrm{KGS}$ per $1 \mathrm{~kg}$. The norm of manual labor is 100-150 kg per day. On average, male loaders earn 500 KGS a day, and women - 200 - 300 KGS per day.

In addition, beans are cleaned using new technologies in large workshops. There are several such workshops in the Kara-Buura district. The minimum batch for cleaning is 5 tons of beans. Workshop services cost 2 - $3 \mathrm{KGS} / \mathrm{kg}$ depending on the degree of beans weediness.

A large workshop is a large enterprise requiring investment in equipment and workshop premises. Local partners (founders) usually provide the premises and facilities, while foreign investors - usually Turkish founders buy equipment and provide workshops with orders for beans cleaning.

Large workshops have several types of equipment:

- A device for cleaning from sand, dust, dirt, stones and plant remains - a sieve

- A machine for sorting beans by color - Sortex type

- A device for sorting beans according to size (8 mm, $9 \mathrm{~mm}$, small seeds)

- A conveyor line for the manual inspection of beans for sorting broken beans, beans damaged by pests - about 20 women work simultaneously

- A line for packaging into the clients' $25 \mathrm{~kg}$ or $50 \mathrm{~kg}$ sacks

- There is also equipment for mechanized beans unloading in bulk 
Approximate cost of the equipment for such high-capacity workshops ranges from 500,000 to $1,000,000$ US dollars.

During periods of low workload due to small orders from major clients, the workshop can provide services to other clients. Small workshops are throughout the region, while large workshops are only in the Kara-Buura district, with some more currently being built in other regions. Previously (4-5 years ago) there were only 2 large workshops, while now there are at least 8 . Cleaning capacity of a large workshop is 3 - 5 tons per hour, with 10 - 30 tons during a shift; from October to December workshops operate in 2 shifts. Large workshops have a maintenance engineer, technicians, operators, loaders and manual personnel (only women). Wages of ordinary personnel in a large workshop are $20 \%$ to $30 \%$ higher than in small ones due to higher labor productivity. Qualified specialists - engineers, technicians-operators receive relatively high payment given local standards (approximately 1000 - 1500 US dollars per month).

The growing need for bean cleaning is a consequence of two different trends. On the one hand, it is market growth and the specialization of business within the established institutional relations between market participants. On the other hand, due to the lack of crop rotation $(80 \%$ of crops in the Kara-Buura and Bakai-Ata districts are beans), monoculture has had a negative impact - bean quality has decreased, while the percentage of defective beans is increasing i.e. damaged beans, small beans, and beans damaged by diseases and pests. Therefore, more effort shall be made to handle yield and, accordingly, greater investment in automated bean cleaning techniques. It can be assumed that this trend will increase.

Figure 11. Large beans cleaning workshop operation (February 2017)

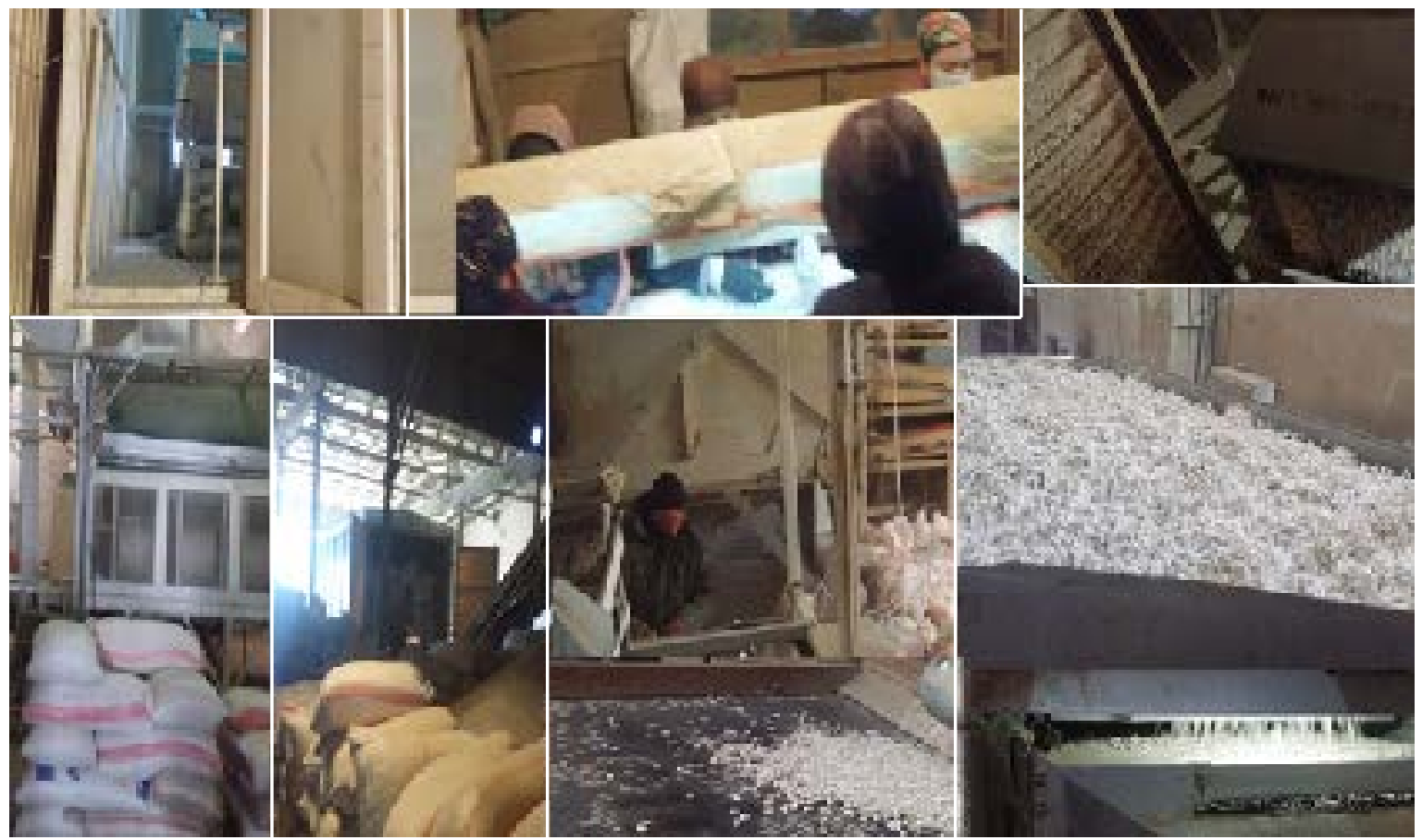

Source: data of the survey

\subsection{Exporters of beans}

The final stage of the beans value chain is a commercial exporting firm. This type of business is represented by a significant number of organizations. According to the survey, over 60 companies in Kyrgyzstan sell beans for further exporting. However, the bulk of exports are organized 
through 10-15 major players in the market. The survey covered 5 firms in the Kara-Buura and Bakai-Ata districts. The main organizational form of the exporting firms are limited liability companies and sometimes individual entrepreneurs to simplify reporting. These firms have a small permanent staff of not more than 30 people, with 10-15 employees on average.

The exporting firms, as well as wholesalers have large warehouses, mainly for beans purveying and finished goods warehouses for beans for export. All firms' warehouses are 1,000 to 1,500 $\mathrm{m} 2$, and have equipment for beans cleaning and sorting, cars and trucks.

Almost all firms have worked 5 - 10 years in the bean purveying market, with on average 5 years of exporting experience. Many firms have Turkish citizens as founders, while some have partnerships with trading firms in Turkey. The average declared supply is 8 - 9 thousand tons per year. At the time of the survey, the average amount in 2016 reached 5,000 tons per firm.

It should be noted that although there are in total more than 60 firms, their number is much smaller in reality. According to the collected information it is clear that 10-12 firms work actively during the season; however many such firms open and close. Several large market players are founders of several companies. Based on the collected information, at least five different legal entities exporting beans were registered at one of the production facilities.

By August - September, the market size is assessed and the level of supply becomes clear. The demand price for beans is formed during this period. Each firm works with several proven suppliers in each zone. Firms work with a group of 20 to 50 suppliers on average. Some firms work only in Kara-Buura district, while others collect beans throughout the region. It is common to place orders and buy ready-made batches. Suppliers buy beans at their own expense and pay immediately. Some firms make prepayment to certain trusted suppliers and prepare formal contracts for the supply of beans. In this case, the supplier undertakes not to sell the prepared order to other firms. This also fixes the price of beans supply.

The average supply varies from 22 to 220 tons, but the average batch of beans for export is 110 tons ( 5 trucks of 22 tons each). The supplied beans can be either cleaned or not cleaned. This affects the price of the beans. Beans are cleaned manually, if the batch is small. In the case of an urgent order, beans are cleaned in a separate cleaning workshop, as described in the previous section. Each operation requires additional efforts and costs - loading, unloading, cleaning, sorting, and repacking. Therefore, usually this preparation is entrusted to wholesalers supervised by the firm and affects the price.

Exporting firms usually prepare a set of documents for export. The list of documents for supply to EAEU countries includes: 1) contract between the parties, 2) laboratory conclusion (certificate that the product is not infected with spongiform encephalopathy - see Annex 2), 3) invoice, 4) logistics agreement with the transport company.

The list of documents for supply to European countries and Turkey: 1) contract between the parties, 2) invoice, 3) logistics contract with a transport company, 4) certificate of conformity, 5) certificate of origin, 6) phytosanitary certificate, 7) customs declaration.

The cost of the set of documents for supply of beans to the EAEU including all official payments is KGS 9,000 per 1 truck (22 tons), as well as unofficial payments of KGS 1,000. The set of documents for exporting to Europe is KGS 2,000, while unofficial payments are the same. Geography of supplies is extensive: 1) EAEU (Russia and Kazakhstan), 2) Europe (Turkey, Belgium, Bulgaria, Macedonia, Serbia and Poland). 
Figure 12. Beans prices at the exporting firms level in 2015-2016, KGS/kg

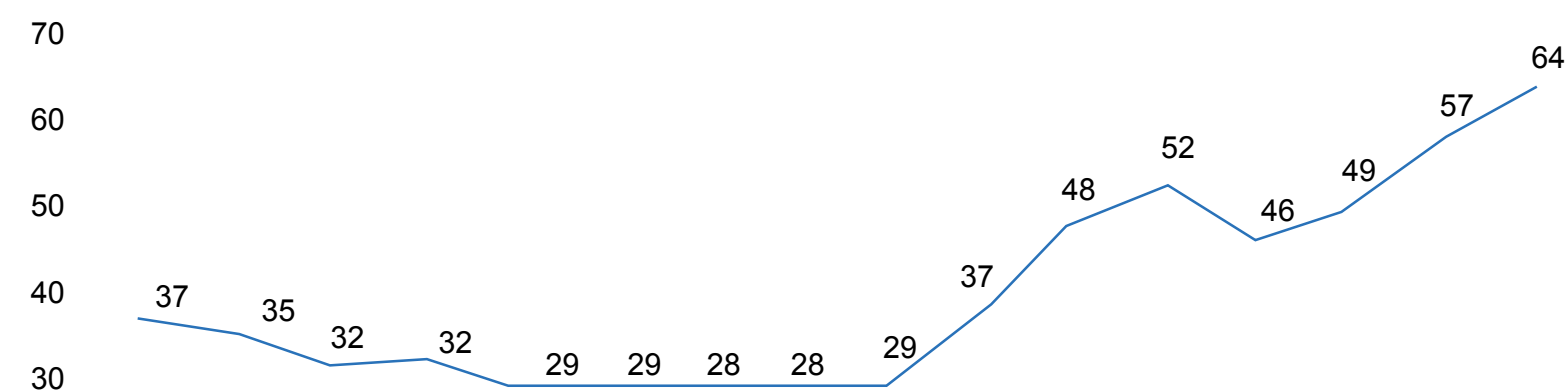

20

10

0

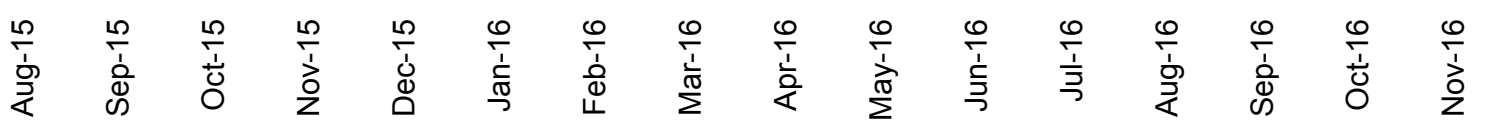

Source: authors' calculations

The average price of beans purchased from wholesalers by exporting firms is generally higher over the concerned period than the price mentioned by wholesalers (by 7\% in October-November 2016). It should be noted that in recent months there has been a significant increase in the price of beans at the level of all value chain participants, which is confirmed by our observations at the wholesalers' level.

Figure 13. Average prices at the farmers (farmers-beans producers and farmerspurveyors), wholesalers and exporters levels by periods in 2015-2016, KGS/kg

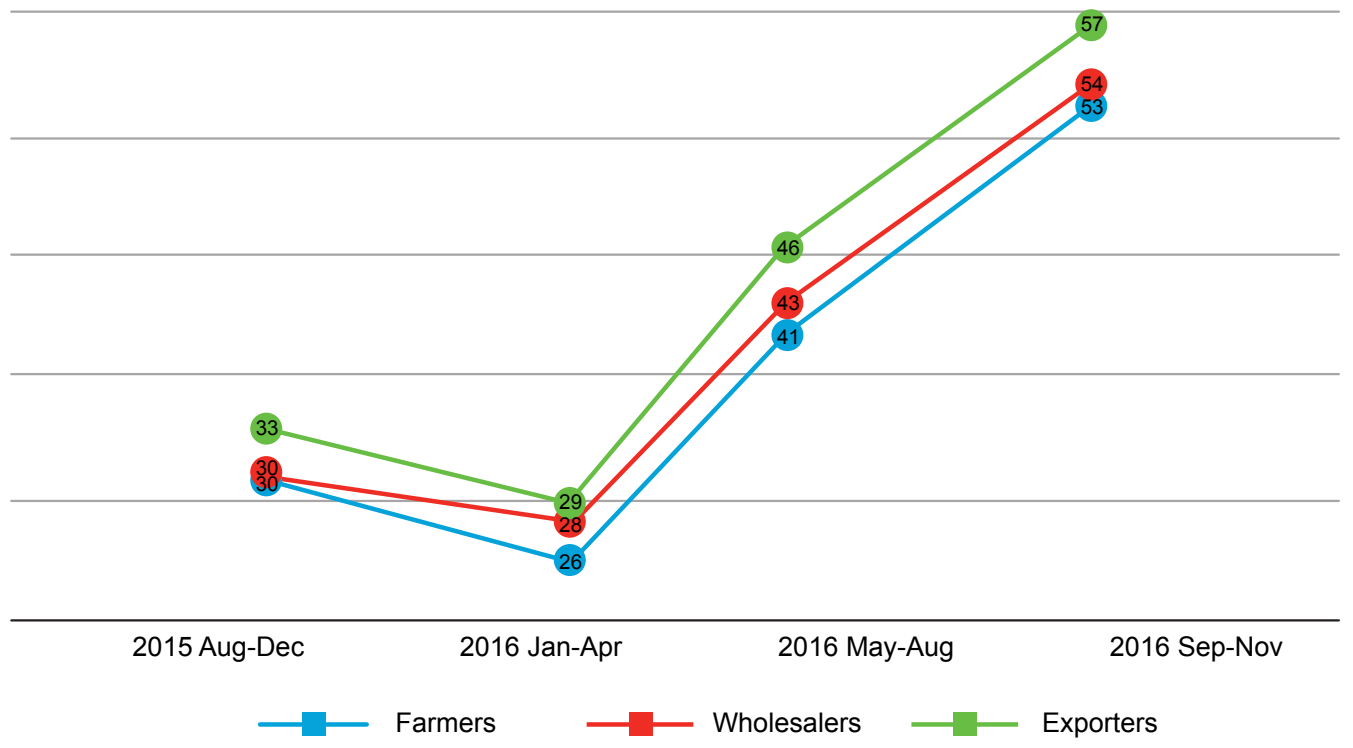

Source: authors' calculations 
Market agents expect an increase in demand in case of limited supply, which is due to favourable market conditions in foreign markets. It is interesting to note that exporting firms are informed about the mark-up on beans in the country of destination after customs clearance. According to their information, exporting firms' mark-up is 5 - 15 KGS per $1 \mathrm{~kg}$ (in the case of Turkey) when selling to the next link in the value chain on the foreign market. Exporters also mention the positive impact of Kyrgyzstan's entry into the EAEU related to the growth of the exports of beans to Russia and Kazakhstan. The main economic driver of growth is the strengthening of the Russian rouble in the second half of 2016. At the same time the weakening of the Turkish lira also contributes to the reorientation of export and its shift from Turkey to Europe and Russia. This trend fuels demand and promotes rush growth.

At the same time, it should be noted that the efforts of the Kyrgyz government are not visible at the level of exporters. The Ministry of Agriculture of the Kyrgyz Republic tried to arrange exports of beans to Pakistan, but the price there was not of interest to exporters. ${ }^{38}$

Also there are government plans to promote Kyrgyz products, including beans, to China. Authorized state bodies should have been prepared and brought to the attention of the Kyrgyz exporters information about the requirements of the Chinese side for imported products in the sphere of technical regulation (certification). ${ }^{39}$

\subsection{Transport companies}

The main means of delivery is road cargo transport. Talas region has several places (TIR parks), where drivers wait for transportation orders - in Kara-Buura and Bakai-Ata districts. Orders for transportation are coordinated and formalized online.

Transport companies are mostly foreign. Kazakh freight carriers based in Shymkent or Taraz operate at the EAEU markets. The cost of delivery ranges from 2,000 to 2,400 US dollars per 1 truck (22 tons). The route goes through: Taraz - Chymkent - Atyrau - Astrakhan (Russian Federation). The destination is the Southern Federal District (Rostov-on-Don, Krasnodar Region). Kazakh drivers mentioned the PLATON ${ }^{40}$ charging system operating in Russia, which makes it more difficult and more expensive for foreign carriers to travel around Russia. The delivery time to Russia is 3-4 days. European routes are mainly operated by Turkish freight carriers. The cost of shipping 1 truck to Europe is 4,000 - 5,000 US dollars. The transport corridor includes the following countries:

- Kazakhstan - Russia (Taraz - Chymkent - Atyrau - Astrakhan) - Georgia - Turkey (7-8 days);

- Kazakhstan - Russia (Taraz - Chymkent - Atyrau - Astrakhan) - Georgia - Turkey - Bulgaria - and further to other EU countries (European Union) (10 days).

38 This information was presented at the seminar during the presentation of the preliminary version of the report on February 28, 2017.

39 Resolution of the Government of the KR No. 82 of February 8, 2017 "On Amendments and Additions to the Resolution of the Government of the Kyrgyz Republic No. 174 "On the Plan of the Government of the Kyrgyz Republic for the Development of Exports of the Kyrgyz Republic for 2015- 2017" dated March 31, 2015".

40 http://platon.ru/ru/ 
At some point, transit through Russia was hindered due to Russian sanctions against Turkey. During the Russian-Turkish aggravation, the route was across the Caspian Sea by ferry through the port of Aktau (Kazakhstan) to the port of Baku (Azerbaijan) and further on to Georgia and Turkey.

The cost of delivery was relatively low, as transport companies usually deliver cargo to Kazakhstan and Kyrgyzstan and, to avoid idle return, they deliver beans to Russia, Turkey and European countries. Sometimes this can delay the supply of beans. The major peak of transportation is in October-December. The second wave of deliveries starts from spring and lasts until mid-summer, as beans stock reduces in the importing countries. In 2015, Kazakhstan banned the departure of empty trucks from its territory, which also affected the sales of beans ${ }^{41}$. The transport companies had to export beans to Kazakhstan and load and dispatch goods from Kazakhstan.

An alternative to road transport is railway transportation from Maimak station. Initially, major shipments passed through it (in the early 2000s), but a number of problems hinder the supply by railway and entailed a decline in transportation by railway:

- The Maimak station is not equipped for container transportation; beans have to be loaded and unloaded manually;

- The wagon park is rather obsolete and exporters are afraid of moisture penetration into the cargo;

- Delivery term is quite long - it takes about a month instead of 10 days;

- There are problems with goods loading - local residents charge too much for loading a wagon, and there was one case with Turkish exporters, who preferred to export beans to Taraz, Kazakhstan and load wagons there;

- Wagon consolidation is more complicated - instead of 20-22 tons, one needs 60 tons of beans or more.

Currently, the amount of railway transportation is about $10 \%$ of the total beans exports

\subsection{Beans value chain structure and its importance for the region's economy}

According to elements described in previous sections, the beans value-added chain can be constructed. The main element of the chain are small farmers: their fragmentation and small size on the one hand is a serious obstacle to productivity growth, while on the other, conditions for free competition at the finished products purchase level, lack of monopoly and distortion of the state are preconditions for maximizing profits at the small market agent level. Let us now consider the share of each level in the gross margin distribution up to the export price level.

${ }^{41}$ http://zanoza.kg/doc/327550_korotko_i_prosto_o_tom_pochemy_v_kyrgyzstane_ejegodno_govoriat_pro_ fasol.html 
Figure 14. Value Chain Scheme

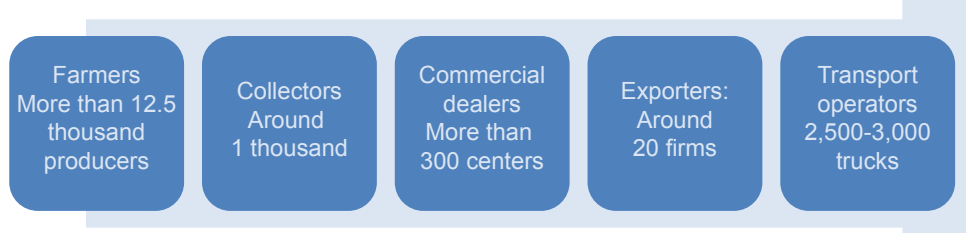

Source: Author's calculations

Table 17. Calculation of the gross margin effect at the farmers-bean producers level in 2016

\begin{tabular}{|c|c|c|c|}
\hline No & & \multicolumn{2}{|c|}{ Quantity } \\
\hline 1 & Approximate number of farmers cultivating beans & \multicolumn{2}{|c|}{12,569} \\
\hline 2 & Cultivated area in 2016 , ha & \multicolumn{2}{|c|}{52,832} \\
\hline 3 & Gross yield in 2016, tons & \multicolumn{2}{|c|}{91,469} \\
\hline 4 & Sales to yield ratio (average for 5 years), $\%$ & \multicolumn{2}{|c|}{$71 \%$} \\
\hline 5 & Expected sales volume, tons & \multicolumn{2}{|c|}{65,095} \\
\hline & & KGS & USD \\
\hline 6 & Sales price, average for October - December 2016, per $1 \mathrm{~kg}$ & 59.3 & 0.9 \\
\hline 7 & Sales volume, $\mathrm{mln}$ & 3,860 & 55.1 \\
\hline 8 & Production cost, per kg & 15.8 & 0.2 \\
\hline \multirow[t]{2}{*}{9} & Production cost, mln & 1,029 & 14.7 \\
\hline & \multicolumn{3}{|l|}{$\begin{array}{l}\text { Production cost, mln } \\
\text { including: }\end{array}$} \\
\hline A & Fertilizers, mln & 168 & 2.4 \\
\hline $\mathrm{B}$ & Pesticides and herbicides, mln & 40 & 0.6 \\
\hline $\mathrm{C}$ & Mechanized works, mln & 401 & 5.7 \\
\hline $\mathrm{D}$ & Manual harvesting, mln & 198 & 2.8 \\
\hline \multirow[t]{2}{*}{10} & Gross margin of farmers-beans producers, mln & 2,832 & 40.4 \\
\hline & including: & & \\
\hline A & Gross margin per 1 hectare of bean crops, thousand & 54 & 0.8 \\
\hline B & per 1 farm, thousand & 225.3 & 3.2 \\
\hline
\end{tabular}

Source: Talas regional department of state statistics, survey results, author's calculations

Calculations at the farmers' level show that the total gross margin share is 2.8 billion KGS, and 225,000 KGS per 1 farm. Indirect effects on the economy of the region include: supply of fertilizers and plant protection means worth over 208 million KGS per year, mechanized works amounting to 401 million KGS, and the labour market for bean harvesting amounting to approximately 200 million KGS. Accompanying effects have an impact on the development of service structures, create local labour markets and develop institutional networks at the local economy level. 
Approximate calculations show that farmers in Talas receive a notable share of the gross margin among the value chain participants (see Figure 15). Even based on approximate calculations, the farmer's share will be within the above figures. Undoubtedly, this distribution is largely due to favourable conditions in foreign markets, but even with a sharp decline in prices, farmers will still receive profit, albeit smaller. The profit of other participants in the beans value-added chain does not depend so much on external prices. However, this explains farmers' behaviour, who even in unfavourable conditions continue to cultivate beans awaiting for conditions of the coming period. No other alternative crop can ensure such profitability.

Figure 15. Approximate calculation of the gross margin distribution among the value chain participants

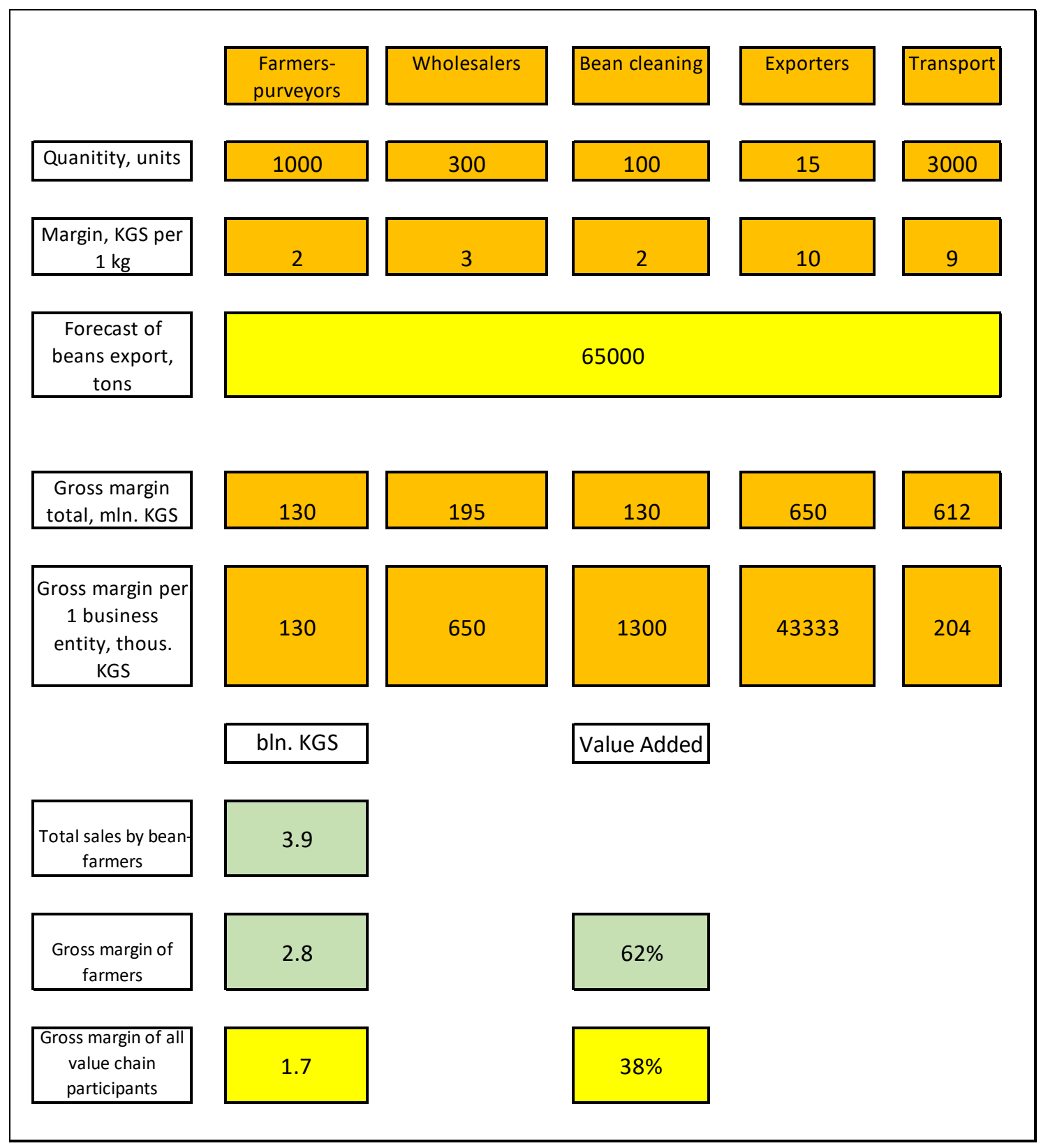




\section{Analysis of phytosanitary and food safety situation and beans marketing}

\subsection{Phytosanitary and food safety}

Bean is a crop, the grain of which has a very dense protective top layer; therefore, it is unpretentious to storage conditions, while rodents do not eat beans. At the same time, beans, like all leguminous crops, are exposed to diseases and are affected by insects and require plant protection means. Common diseases include viral mosaic, anthracnose, fusariosis, and bacteriosis. Pests, such as the sprout fly and the Lima-bean pod borer also eat beans (see Table 18)

Table 18. Information on the spread of bean diseases and pests in Kyrgyzstan in 2012-2015, ha

\begin{tabular}{|c|c|c|c|c|}
\hline Pests & 2012 & 2013 & 2014 & 2015 \\
\hline Sprout fly - Delia platura & - & 1,952 & 1,853 & 129 \\
\hline Lima-bean pod borer - Etiella zinckenella Tr. & - & 567 & 1,067 & 255 \\
\hline Common spider mite - Tetranychus urticae & - & - & - & 4711 \\
\hline Fusariosis - Fusarium oxysporum sch. & 1,038 & 4,876 & 2,316 & 5,322 \\
\hline $\begin{array}{c}\text { Bacteriosis (brown bacterial spot and angular spot) - } \\
\text { Xanthomonas phaseoli Dowson }\end{array}$ & - & 1,338 & 4,396 & 1,346 \\
\hline Powdery mildew & - & - & - & 178 \\
\hline Beans rust & - & - & - & 61 \\
\hline Pea aphid - acyrthosiphon pisum Harr. & - & - & 1,952 & - \\
\hline Nodule weevil & 2,484 & 3,578 & - & - \\
\hline
\end{tabular}

Source: Department of Chemicalization and Plant Protection of the Ministry of Agriculture Food Industry and Land Reclamation of KR

Anthracnose and fusariosis are fungicidal bean diseases and are transmitted through seeds. Anthracnose and fusariosis can develop throughout the vegetative period of plants and can affect all parts of the plant ${ }^{42}$. A rainy and an early spring can contribute to the development of anthracnose and fusariosis. In 2015, fusariosis infected 5,322 ha (10\% of the total area under bean) and infected $3-25 \%$ of plants in the surveyed areas ${ }^{43}$. Surveys on anthracnose infection were not conducted, but according to expert estimates, up to $50 \%$ of plants are infected. Loss of productivity as a result of anthracnose is up to $30 \%{ }^{44}$.

There are several types of bean mosaic - common or green and yellow mosaic, which differ by plant colour in the case of disease. In the early stages of development infected plants do not bear fruit, and in the late stages they produce a very low yield. The yield loss in the case of mosaic infection is up to $90 \%{ }^{45}$ No mosaic infection was registered in 2015; however, according to experts, plants cultivated in the Talas region are infected with mosaic.

Bacteriosis is a bean disease caused by bacteria. Its emergence and development depend on the infectious origin, the degree of plants susceptibility and environmental factors. Regardless of the bacteriosis type, the disease is persistent and durable. In 2016, 1,346 ha were affected by bacter-

42 SAK (2013) Guidelines to Bean Seed Production

43 Department of Chemicalization and Plant Protection under the Ministry of Agriculture, Food Industry and Land Reclamation of KR (2016) Overview of the emergence and spread of major agricultural crops pests and diseases in the Kyrgyz Republic in 2015 and forecast of their emergence in 2016.

44 National Academy of Sciences of the Kyrgyz Republic, 2015

45 Ibid 
iosis $\left(2.5 \%\right.$ of the total area under bean), with $5-20 \%$ of plants damaged in the surveyed area ${ }^{46}$. Bacteria persist on seeds and remainings of affected plants in the field and may cause the death of seedlings and adult plants in subsequent years. Bean diseases spread through the re-seeding of infected seeds, as well as through plant residues that remain in the fields after harvesting. Wide coverage of the infection is due to the lack of crop rotation, i.e. accumulation of pests and diseases in the fields ${ }^{47}$, as well as the lack of seed renewal. According to SAK expert opinion, farmers in Kyrgyzstan continuously use seeds that were produced from those imported back in the 1990s. Farmers keep larger seeds of their own production for sowing; they also exchange seeds with each other, thereby transmitting diseases from one field to another. Some large farmers can afford to import certified seeds, but they do not share them with their neighbours. In addition, diseases are transmitted through insects - aphids (such as mosaic).

Unfortunately, bean diseases are resistant to herbicide treatment. The best method for their control is to plant uninfected seeds, destroy plant residues after harvest, and cut and burn infected parts of plants ${ }^{48}$. Another alternative way to combat diseases is to cross existing varieties with those that are resistant to diseases. Studies conducted by S. Hegai on the development of genetic methods to combat diseases such as mosaic and anthracnose showed that this crossing is possible and provides positive results ${ }^{49}$. However, it is necessary to continue long-term studies on bacteriosis control.

As for pests, in 2015 the most widespread and harmful were sprout fly, aphids, mites and Lima-bean pod borer, and to a lesser extent - nodule weevils and bean weevil.

Sprout fly harms all legumes damaging germinating seeds and sprouts, and spreads in warm and humid climates. Since 2015 was quite arid, harm caused by the sprout fly was less noticeable compared to previous years. Sprout fly control measures include chemical treatment, careful soil treatment, removal of plant residues and soil loosening.

The Lima-bean pod borer damages the fruit of plants by eating seeds. It hibernates in the soil and damage is caused mainly by the second-generation caterpillars. As a result of aridity in 2015, harm caused by Lima-bean pod borer was lesser compared to other years.

Melon aphid is a widespread pest and damages adult plants, sucking juice from sprouts and leaves. In addition, aphids are dangerous because they transmit viral and bacterial diseases. Aphid control measures also include chemical treatment.

Despite existing diseases, people can eat damaged beans, as they do not bear risk to human health, while grains damaged by pests are carefully sorted and disposed of. Perhaps, that is why little attention is paid to this problem in Kyrgyzstan. According to representatives of public organizations, research institutes and businesses, currently the state does not take appropriate efforts to improve the quality of seeds through the development of seed farms, as well as training and informing farmers about diseases, pests and methods of their control.

The authorized bodies for plant protection in Kyrgyzstan are the State Department for Plant Chemicalization, Plant Protection and Quarantine (DPCPPQ) and the Republican State Seed In-

46 Department of Chemicalization and Plant Protection under the Ministry of Agriculture, Food Industry and Land Reclamation of KR (2016) Overview of the emergence and spread of major agricultural crops pests and diseases in the Kyrgyz Republic in 2015 and forecast of their emergence in 2016.

47 A. Asanaliev, S. Hegay (2012). Identification and introduction of resistance genes into cultivated bean varieties in Kyrgyzstan.

48 Department of Chemicalization and Plant Protection under the Ministry of Agriculture, Food Industry and Land Reclamation of KR (2016) Overview of the emergence and spread of major agricultural crops pests and diseases in the Kyrgyz Republic in 2015 and forecast of their emergence in 2016.

49 A. Asanaliev, S. Hegay (2012). Identification and introduction of resistance genes into cultivated bean varieties in Kyrgyzstan. 
spection (RSSI) of the Ministry of Agriculture, Water Resources and Processing Industry of the Kyrgyz Republic. Annex 1 describes their activities and the regulatory framework for plant protection and seed fund improvement.

The state regulates the export of beans based on general legislation, and no further efforts are currently made to promote their export. The state is focused on other subsectors of the agrarian sector, such as, for example, grain markets or the livestock sector.

According to the entrepreneurs - beans exporters, they shall only need phytosanitary certificate and certificate of origin for exporting products to foreign markets. They are not sure about requirements in other markets. The initial visual inspection is implemented by manufacturers, then samples are sent to the DPCPPQ for obtaining a permit for export. Non-tariff barriers of the EAEU and some bean importing countries are summarized in Annex 2. More detailed information on food safety and phytosanitary control is in Annex 2 - Tariff and non-tariff barriers of potential export markets when exporting beans.

\subsection{Analysis of potential beans markets}

\section{Potential markets - bean importing countries}

In recent years, the main consumers of Kyrgyz beans are: Turkey, Serbia, Bulgaria and Russia. However, there are other large bean consumers that may be potential importers of Kyrgyz beans - India, Pakistan, Iran, the EU (in addition to Bulgaria and Serbia), and South Korea (see Figure 16). Turkey and Russia are already current partners of Kyrgyzstan.]

Table 19 shows domestic production, the area under bean and yield of the largest bean importers in 2014. Kyrgyzstan already supplies beans to South European countries through a network of traders connected with the Turkish diaspora in Europe, so supply to Italy or Spain will not be easy due to the lack of well-known brands, as well as non-conformity with European bean varieties. Out of the countries in the table, we will consider Pakistan and South Korea as potential countries for beans export.

Figure 16. Import of beans in 2015 by the largest importers

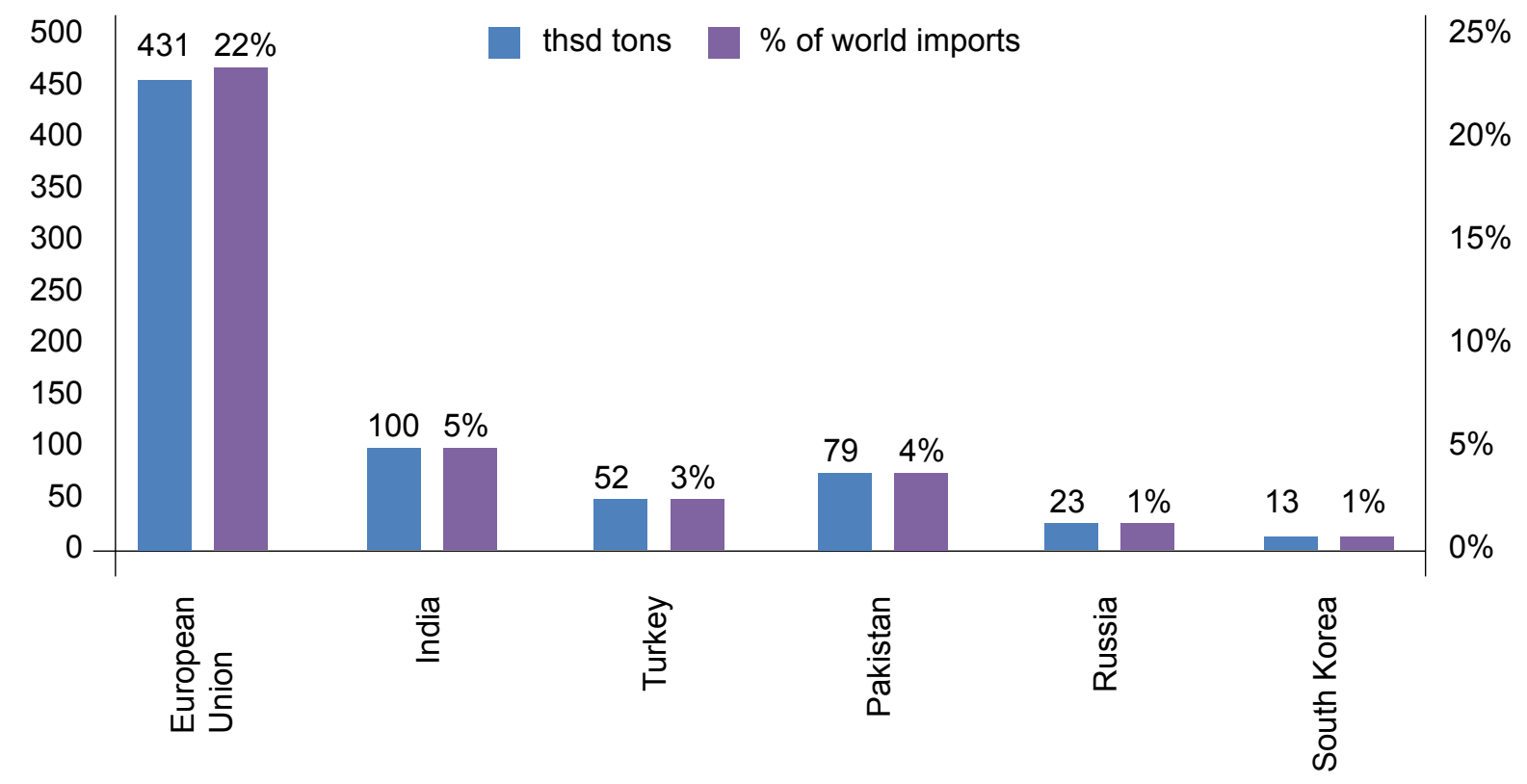


Table 19. Production, area and yield of the largest bean importing countries ${ }^{50}$ in 2014

\begin{tabular}{|c|c|c|c|c|}
\hline & $\begin{array}{c}\text { Production, } \\
\text { thousand } \\
\text { tons }\end{array}$ & $\begin{array}{c}\text { Area, } \\
\text { thousand } \\
\text { ha }\end{array}$ & Yield, tons/ha & $\begin{array}{c}\text { Supply, kg/ } \\
\text { person/year }\end{array}$ \\
\hline India & 4110.0 & $1,862.0$ & 0.41 & 3.04 \\
\hline Turkey & 215.0 & 90.5 & 2.38 & 2.69 \\
\hline Pakistan & 107.9 & 148.2 & 0.73 & 1.04 \\
\hline Russia & 7.1 & 4.1 & 1.75 & - \\
\hline South Korea & 9.3 & 8.2 & 1.13 & 1.03 \\
\hline European Union & 228.6 & 110.9 & 2.27 & 0.78 \\
\hline Italy & 11.0 & 4.9 & 2.25 & 1.94 \\
\hline Spain & 13.0 & 7.9 & 2.18 & 1.03 \\
\hline World (total) & $26,529.6$ & $30,612.8$ & 0.87 & 1.04 \\
\hline
\end{tabular}

Source: FAOSTAT database

Legumes are traditionally consumed in Pakistan, and the major crops produced are garbanzo, lentils, mung beans and dried beans (including beans). Despite the high consumption of beans (supply of dried beans is $1.04 \mathrm{~kg}$ /person/year, supply of all beans is $2.2 /$ person/year ${ }^{52}$ ), their yield is relatively low. This is due to the fact that bean is cultivated on rainfed lands. In legumes consumption per capita in Pakistan, beans consumption is low (4\%), but a large growing population is of interest to those who wish to expand the export of beans. In addition, there are differences in legumes consumption depending on the region. Mung beans and green peas are consumed throughout the country due to their low cost, lentils are consumed in the north and east of Pakistan, and red beans, mostly only in the northern regions ${ }^{53}$. The major exporters of beans to Pakistan in 2015 were Ethiopia (54\% of bean imports), Brazil (11\%), Kenya (8.2\%), China (6.3\%) and Argentina (5.4\%) ${ }^{54}$.

In South Korea, the consumption of legumes is not so common, as the main crops being consumed are rice and soybeans. Consumption of legumes was $2.6 \mathrm{~kg}$ per person $(3.7 \%$ of all cereals ${ }^{55}$. Currently, beans to South Korea are supplied from Canada (38\%), China (39\%), the United States (8\%), and Myanmar (8\%) ${ }^{56}$.

\section{Major competitors - bean exporters}

The world's largest suppliers are shown in Figure 17 Argentina supplies beans to Latin American countries, while the USA and Canada are suppliers to European countries. The main competitors

50 Data are presented for dried legumes Vigna Radiata, Vigna mungo (FEA CN 071331), adzuki beans (071332), common beans (071333) and other beans (071339).

51 These countries grow legumes mainly on rainfed lands, so the yield is quite low, while beans in Kyrgyzstan are grown only on irrigated lands.

52 FAOSTAT database

53 Ibid

54 UN COMTRADE database

55 Statistics of Korea http://kostat.go.kr/portal/eng/pressReleases/2/11/index.board

56 UN COMTRADE database 
of Kyrgyzstan in the markets of Pakistan, India and Turkey are China, Egypt, Ethiopia (see Table 20).

Figure 17. The largest beans exporting countries in 2015

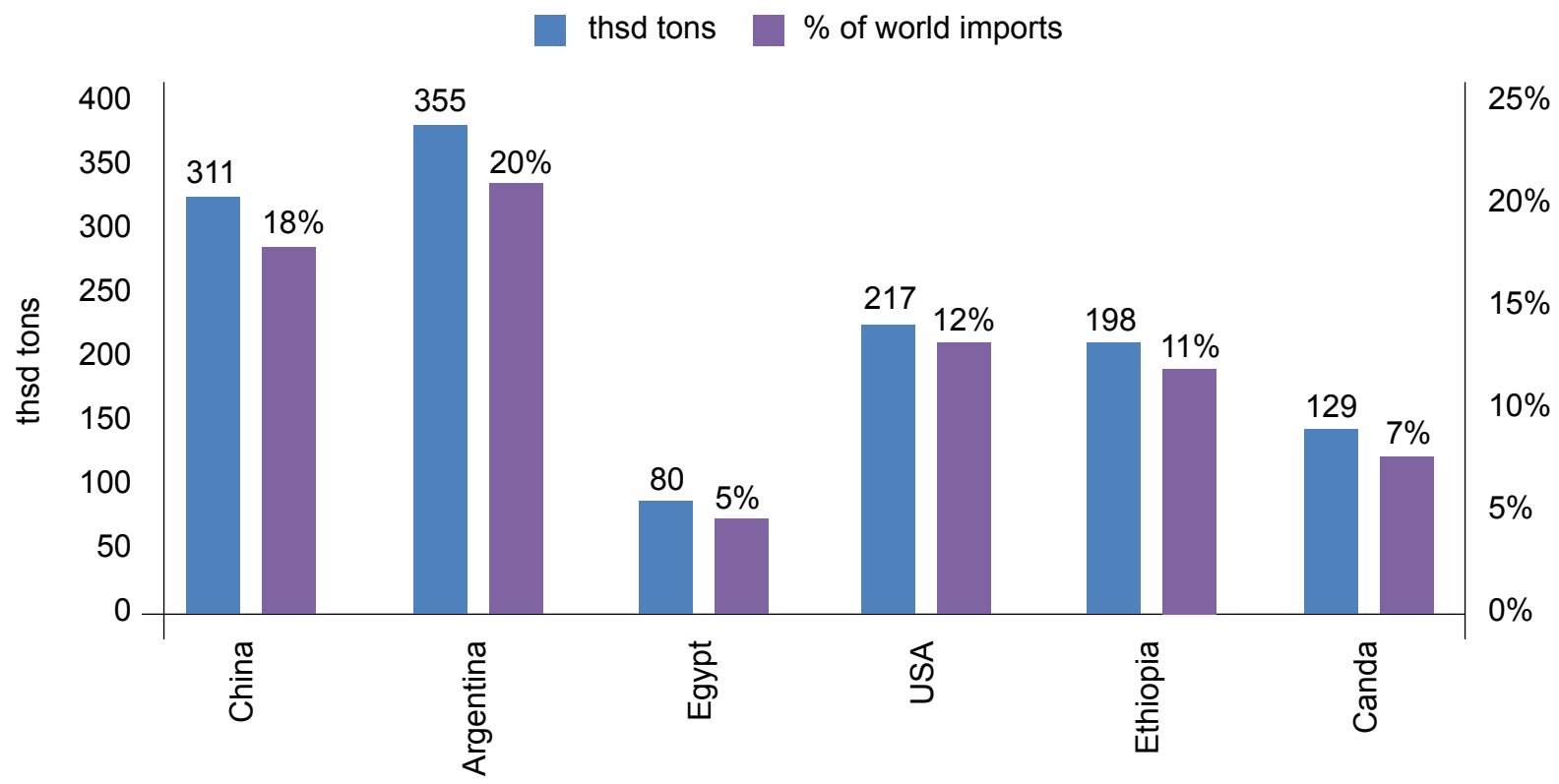

Source: UN COMTRADE

Table 20. Production, area and yield of major producers of dried beans

\begin{tabular}{|c|c|c|c|c|}
\hline & $\begin{array}{c}\text { Production, } \\
\text { thousand tons }\end{array}$ & $\begin{array}{c}\text { Area, } \\
\text { thousand ha }\end{array}$ & Yield, tons/ha & $\begin{array}{c}\text { Supply, kg/ } \\
\text { person/year }\end{array}$ \\
\hline China & $1,061.8$ & 605.9 & 1.75 & 0.08 \\
\hline Egypt & 127.1 & 45.9 & 2.77 & 0.40 \\
\hline Ethiopia & 513.7 & 323.3 & 1.59 & 2.09 \\
\hline
\end{tabular}

Source: FAOSTAT database

China is one of the largest beans exporters in the world. Beans produced in China are not consumed domestically and are exported ${ }^{57}$. The export of beans is formed due to the demand in foreign markets. Thus, for example, low production in importing countries forms a higher price and, accordingly, stimulates an expansion of areas under bean in the country. The yield of beans remains relatively stable and depends on climatic conditions. Beans are grown in the north-eastern part of China $^{58}$.

Legumes production and export is very important for the economy of Ethiopia, being the third largest after the export of coffee and sesame ${ }^{59}$. Ethiopia produces the following varieties of legumes - horse beans (Faba beans), beans and garbanzo. The development of legume exports in Ethiopia is similar to the cultivation of this crop in Kyrgyzstan: the export of legumes is an im-

57 US Department of Agriculture/Agricultural Outlook of Legumes Market in China, 2014.

$58 \quad$ Ibid

59 International Food Policy Research Institute (IFPRI)/Legumes Value Added Chain in Ethiopia. 2010 
portant source of income for small farms and is sensitive to fluctuations in prices in the world markets ${ }^{60}$. However, unlike Kyrgyzstan, a large amount of legumes $-2.09 \mathrm{~kg} /$ person/year is consumed domestically as a source of protein, fodder, fertilizers; the remaining goes for export. The major consumers of Ethiopian beans are Pakistan (23.5\% of beans imports), India (17.8\%), Kenya $(13.2 \%)$ and Russia $(6 \%)^{61}$.

Egypt is the main competitor of Kyrgyzstan in the Turkish market. In 2014, beans import from Egypt to Turkey was 12,000 tons $^{62}$, while in 2015 it was 2.5 thousand tons, which was due to low yield. The export of beans from Kyrgyzstan depends on beans production in Egypt ${ }^{63}$. The main varieties of legumes produced in Egypt are horse beans and beans sown between sugar cane and beet beds enriching the soil. The advantage of Egyptian beans is the climatic conditions - bean is planted in autumn and yields in spring, while bean in Kyrgyzstan is harvested in autumn.

The lowest producer prices are those of Ethiopia and Egypt, and as a result they are major competitors for Kyrgyzstan. China is competitive due to large volumes of supplies.

Table 21. Producer prices for dry beans, USD/ton, 2014

\begin{tabular}{|c|c|c|c|}
\hline & 2012 & 2013 & 2014 \\
\hline China & $1,286.8$ & $1,307.5$ & 727.1 \\
\hline Egypt & 840.2 & 776.2 & 367.7 \\
\hline Ethiopia & 588.5 & 424.4 & $1,298.9$ \\
\hline Kyrgyzstan & 642 & 877.3 & \\
\hline
\end{tabular}

Source: FAOSTAT database

\section{Transport costs}

The main obstacle to Kyrgyzstan's entry to potential trade markets is complicated logistics of the supply: remoteness from seaports, location in highlands, and a lack of rail infrastructure. Kyrgyzstan has currently no direct connection with South and East Asia. The Karakoram Highway through China to Pakistan could potentially be an option, but it should be taken into account that China is not a party to the TIR agreement. In order to calculate supply, representatives of the surveyed transport companies proposed to use multimodal transportation (railway or sea transport combined with road transport).

For exit to ports of China from the existing railway lines, the route Almaty (Kazakhstan) - Druzhba (Kazakhstan-China) - Urumqi - Lianzhu - ports of Qindao, Lianyungang, Shanghai can be used (see Figure 18A - Central Asia - China). Further from these ports beans can be delivered to North-East Asia. The approximate cost of transporting a 40-foot container (about 22 tons) to South Korea will be $\$ 7,000^{64}$ or about $30 \%$ of the cargo cost.

\footnotetext{
$60 \quad$ Ibid

61 UN COMTRADE database, 2015

62 UN COMTRADE database, reporter - Turkey.

63 http://zanoza.kg/doc/345265_plohoy_yrojay_v_argentine_i_egipte._cena_na_fasol_kr_vyrosla_do_58_somov.html

64 Assessment made by the surveyed transport company
} 
Figure 18. Options for cargo delivery from Kyrgyzstan to South Korea and Pakistan.

A) Central Asia - China

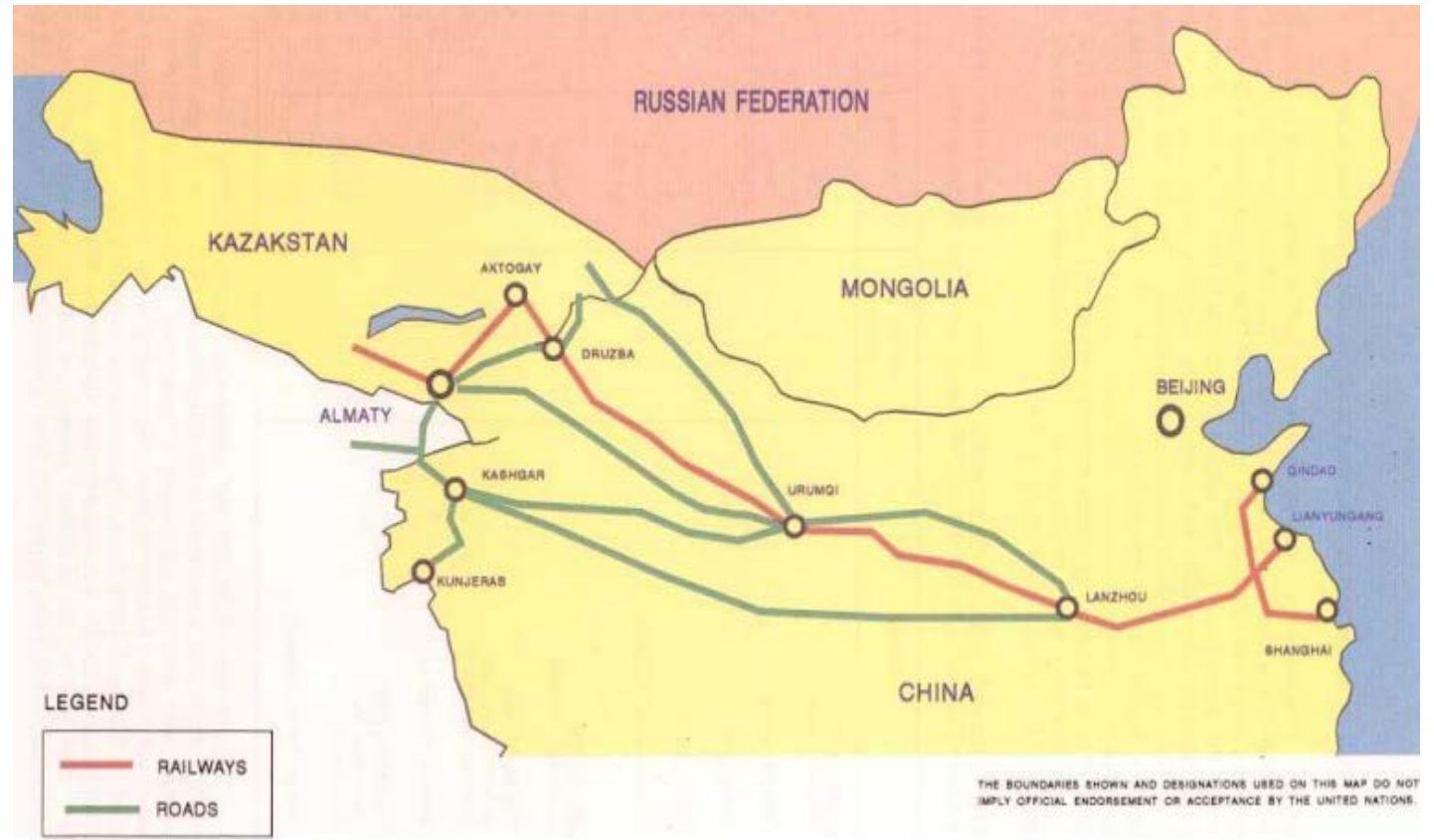

B) Central Asia - Southern Asia

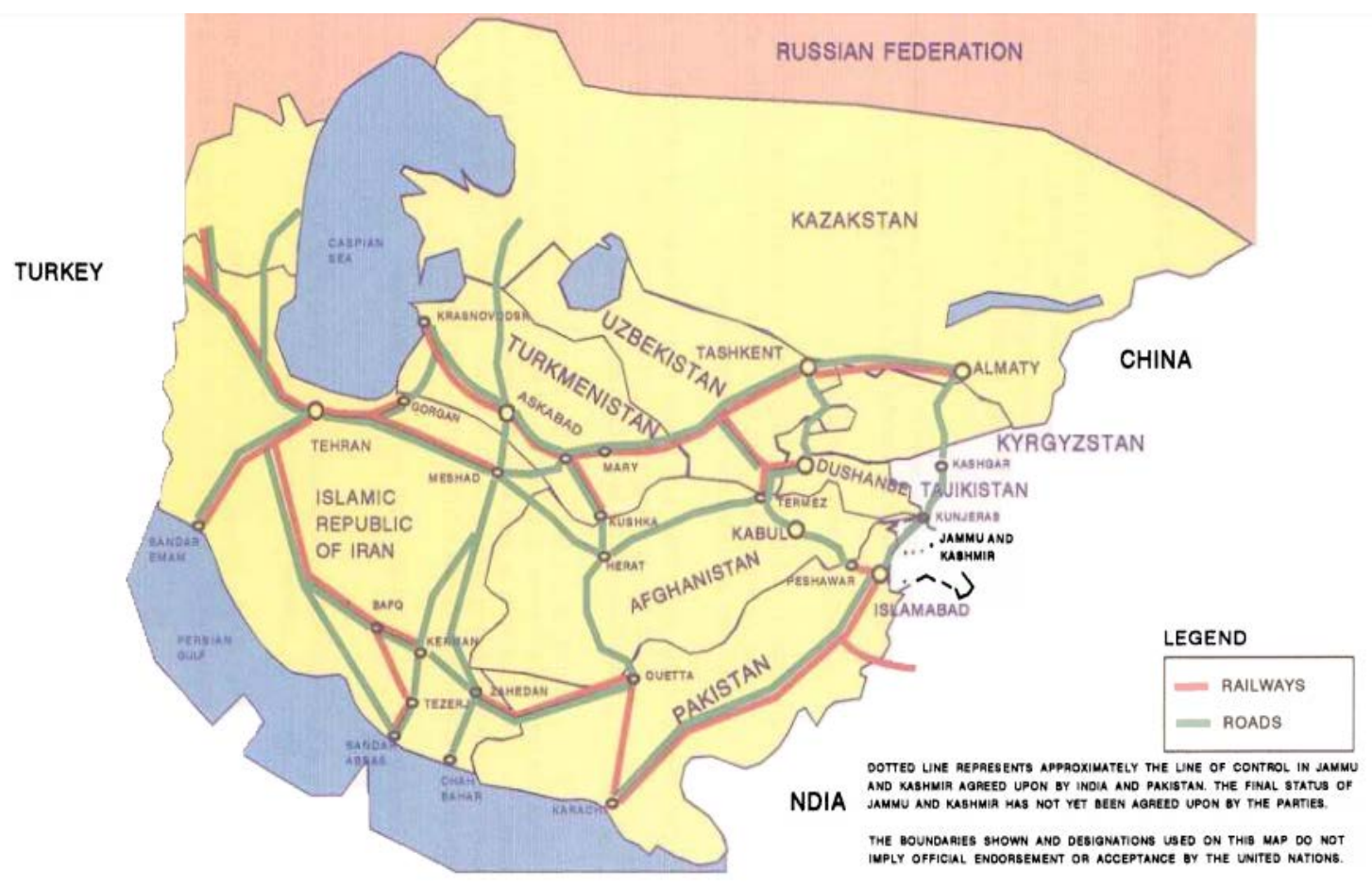

Source: UN ESCAP http://www.unescap.org/sites/default/files/pub_1560_ch3.pdf

It is more difficult to get to the ports of South Asia (See Figure 18B - Central Asia - Southern Asia). Transport companies prefer the automobile route Bishkek/Talas (Kyrgyzstan) to the port 
of Bandar Abbas (Iran) and then by sea to the ports of Pakistan and India. The approximate cost of transporting a 40-foot container by road to Bandar Abbas (Pakistan) is estimated at $\$ 7,000^{65}$.

At present, the export of beans to South Korea and Pakistan seems unlikely. It must be taken into account, however, that the export of beans to Turkey also seemed unlikely and required arduous work by Turkish businessmen. In fact, the supply of beans to Turkey, Europe or Russia is economically feasible only if there is counter transport traffic to Kyrgyzstan or a neighbouring country; otherwise an exporter has to pay the cost of an idle transit run on the way back.

Thus, establishment of trade relations with potential countries to export beans to will be sustainable for Kyrgyzstan only if there is a two-way flow of goods over a number of years.

\section{Conclusion and recommendations}

Over the past 15-20 years the bean industry in the Talas region of Kyrgyzstan has grown into a leading sector of the regional economy, which has become the main source of income growth and poverty reduction among its population. The scale and speed with which a relatively new culture has spread, its geographical location, as well as its apparent export orientation are unprecedented in the agriculture of Kyrgyzstan. Obviously, it is access to export markets that is the decisive factor in the success of this industry. Another important factor contributing to the spread of bean production has been a high level of competition at all stages of the value chain. Competition and the accompanying lack of added value concentration at some point in the chain contribute to the division of benefits from export and the maintenance of reasonable profitability for all participants of the production process. An almost complete absence of state regulation has allowed this industry to form as a self-regulating cluster with relatively low transaction costs. Natural and climatic conditions favourable for growing beans, geographical concentration of production and convenient location of the region next to international automobile and railway highways have also played a part in industry development.

However, the growth of the bean industry in the Talas region of Kyrgyzstan is associated with a number of significant factors that are not easy to copy for another region with similar climatic conditions. These factors are the following:

- a group of farmers in the region with historical experience in bean cultivation, which can be easily copied by other nearby farmers;

- $\quad$ an absence of other attractive prospects for the development of agricultural production and employment in the region during the period of the bean industry launch (from the mid-1990s to the mid-2000s), which reduced alternative costs for the introduction of the bean industry.

Despite the success achieved, the bean sector faces a number of production and institutional obstacles and constraints, an insufficient level of state support, a lack of knowledge and information support as well as dependence on the conjuncture of foreign markets. These obstacles and limitations include:

65 Transportation company data 
- The extensive increase in production has exhausted itself. The Talas region has practically no more land left for the cultivation of beans. In the Bakai-Ata and Kara-Buura districts with a suitable natural environment, over $80 \%$ of the arable land is already used for beans. Beans have become a monoculture, and when crop rotation fails its cultivation gradually brings more harm to the soil and ecosystem of the region.

- Failures in crop rotation and agricultural technology are also related to a lack of farmers' capital. Inadequate chemicalization and often its misuse reduce soil fertility and contribute to an increase in plant diseases and the spread of pests.

- There is a low level of production mechanisation and still a high proportion of manual labour that hinders higher performance and the active development of the sector.

- The predominance of small producers in the sector makes it impossible to take advantage of economies of scale. Distrust among farmers is the reverse side of competition. This prevents the formation of service cooperatives and other forms of production process organizations that would lead to specialization and increased efficiency. Cooperation rarely goes beyond family networks.

- A complex organically-grown institutional structure of producers - farmers, dealers, exporters, technology services (drills, harvesters, tractors) - hinders the simple transfer of experience from the Talas region to other regions of the country.

- State aid in seed growing and plant protection appears to be completely inadequate. In case the situation does not change in the Talas region, the growth of plant diseases and pests is possible.

- A limited level of bean farmers' agronomic and marketing knowledge reduces potential performance growth; this situation remains even though there is a high solvent demand for information among farmers.

- There is almost no domestic demand for beans in Kyrgyzstan, which increases industry vulnerability to the whims of the international market of only one product, and to external factors beyond the control of market participants and public authorities, among which include the following:

- Currency devaluation in countries importing beans (Russia in 2014-2015, Turkey in late 2016) reduces price competitiveness of Kyrgyz products, thus endangering the stability of the market in medium- and long-term periods;

- Unfavourable weather conditions can dramatically reduce farmers' crops;

- Favourable conditions in other countries producing beans may lead to an increase of supply at international markets and a decline in export prices for bean farmers in Kyrgyzstan.

Taking into account all abovementioned factors, the following recommendations can be suggested for the development of the bean industry in the Talas region and in Kyrgyzstan.

\section{Recommendations for state bodies:}

- To support the development of service cooperatives and private procurement companies supplying bean farmers with seeds, fertilizers, means of plant protection, fuel, harvesting 
services and the organised sale of the produce through the provision of preferential funding with low interest rates in the framework of existing agriculture support programs.

- To summarize data and inform farmers and the private sector in other regions of Kyrgyzstan with similar natural and climatic conditions about Talas region bean farmers' experience and success, providing a detailed description of not only production processes, but also post-harvest processing and the organization of bean sales by intermediaries and exporters.

- To develop and implement a regional program focused on overcoming a lack of literacy among farmers about chemicals, agricultural technology and the introduction of new techniques.

- To introduce target preferential funding for the purchase of an improved means of production by farmers - seeds, effective fertilizers and means for plant protection

- To strengthen state and/or private quality infrastructure and state control over the means of chemicalization in agriculture.

- To support the development of modern means of disease and pest diagnostics given new information technologies, specifically, to fund the development and spread of mobile internet applications among farmers for fast diagnostics of diseases, the identification of bean pests and options to deal with them.

- To strengthen farmers' training through the establishment of an integrated system of training, including traditional mass media means, internet, development of training manuals and courses, including questions discussed in the previous paragraph.

- To find funds and implement a multi-year research program to develop improved bean seeds that produce high yield and are resistant to diseases, pests and climate change, as well as to develop and introduce agricultural technologies into the bean industry, which would allow soil fertility to be maintained.

- To develop and implement a program to increase domestic demand for beans as a valuable nutritious product, using mass media, and to carry out outreach activities to promote balanced diets including beans.

- To initiate/support experimental work in the Talas region and other regions of the country on growing and adapting other crops with high nutritional and economic value in order to reduce dependence from beans monoculture.

- To support private sector organizations in carrying out a systematic search for new potential international markets for beans from Kyrgyzstan.

- To avoid the use of child labour in bean production, to strengthen the monitoring from relevant authorities on child labour use in agriculture, to continue informing the population about potential dangers of child labour in regard to their health and education.

- To monitor compliance with women's statutory rights for equal access to land, equal pay for labour, compliance with work safety standards (especially when cleaning beans) and, if necessary, restoration of violated rights.

\section{Recommendations for bean farmers and their associations:}

- To focus efforts on the establishment of service (rather than production) cooperatives in the first place, using transparent and trust-building forms and rules of organisation, which 
should provide an increase in bean production efficiency. To establish production cooperatives only when having mutual trust and highly effective managerial schemes.

- To invest time and effort in acquiring knowledge on the production and sale of beans, to establish and actively participate in platforms on the accumulation of knowledge and experience exchange, including platforms online, in the field of agricultural technologies, the fight against diseases and pests, the use of medications and fertilizers, as well as seed selection.

\section{Recommendations for development organisations:}

- To focus resources on the support of research in the improvement of agricultural technology methods and assistance in the creation of high-yield sorts of beans, resistant to diseases and climate change.

- To support government agencies and farmers in securing access to the best international practices in the cultivation and sale of beans, including both technological and economic solutions (improvement of beans' genetic material, disease control methods, information on markets, etc.), as well as institutional issues (establishment of transparent and sustainable service cooperatives, etc.).

- To conduct informational work and to continue to support the activities of the state and public organisations on compliance with economic and social rights of women and children.

\section{Sources}

Asanaliev A., Hegay S. (2012) Identification and introduction of resistance genes into cultivated bean varieties in Kyrgyzstan

Bolotova M.A. (2010) Development of the agrarian sector of the economy in market conditions (as in the case of the Talas region) - dissertation for the degree of Candidate of Economic Sciences, KNU n.a. J. Balasagyn

Department of Chemicalization and Plant Protection under the MAFIR KR (2016) Review of appearance and spread of major pests and diseases among agricultural crops in the Kyrgyz Republic in 2015 and their projected appearance in 2016.

Department of Chemicalization and Plant Protection under the MAFIR KR (2016) Review of appearance and spread of major pests and diseases among agricultural crops in the Kyrgyz Republic in 2015 and their projected appearance in 2016.

US Department of Agriculture / Agricultural Outlook for Legumes Market in China, 2014.

International Food Policy Research Institute (IFPRI) / Legumes Added Value Chain in Ethiopia. 2010

NSC KR, compilation Agriculture, 2008-2012, 2010-2014

NSC KR, compilation Foreign trade, 2010-2014.

NSC KR, compilation Arable lands for agricultural crops in 2012.

NSC KR, Population and Housing Census of the Kyrgyz Republic in 2009. Book 3. Talas region, Bishkek, 2010 
NSC (2015) Kyrgyzstan in figures

NSC (2016) Rural population size according to ayil okmotu data as of the beginning of 2016.

Seed Association of Kyrgyzstan (2013), Guidelines for Seed Bean Production

Summary on harvested crops in regions and districts of the Kyrgyz Republic on September 24, 2016, Ministry of Agriculture, Processing Industry and Land Reclamation of the Kyrgyz Republic

Tilekeev K.A. (2013) Indirect effect of participation in export activities on productivity: An example of farmers in the Talas region of Kyrgyzstan. University of Central Asia, Report No. 17

Minahan, J. The former Soviet Union's diverse people: a reference sourcebook. ABC-Clio, 2004

Tilekeev, K. Rural Poverty Determinants in the Remote Rural Areas of Kyrgyzstan: A Production Efficiency Impact on the Poverty Level of a Rural Household. (Monograph), Peter Lang, Frankfurt am Main, 2014. XII, 234 pp. ISBN 978-3-631-65093-6 hb

\section{Internet-resources}

http://comtrade.un.org

FAOSTAT Database

http://24.kg/obschestvo/22728_premer-ministr_prizval_kyirgyizstantsev_est_bolshe_fasoli/ http://www.turmush.kg/ru/news:262263

http://vwww.gezitter.org/economics/53573_rastut_tsenyi_na_fasol_/ http://ontariobeans.on.ca/world-bean-production-outlook-2015/ http://24.kg/obschestvo/22728_premer-ministr_prizval_kyirgyizstantsev_est_bolshe_fasoli/ http://kostat.go.kr/portal/eng/pressReleases/2/11/index.board http://www.customs.kg/index.php/kg/custstat/115-sbtamstvntr/130-sbstsvntr http://www.customs.kg/index.php/kg/custstat/115-sbtamstvntr/130-sbstsvntr http://www.fao.org/faostat/en/\#data/TP http://www.customs.kg/index.php/kg/custstat/115-sbtamstvntr/130-sbstsvntr http://vwww.gezitter.org/economics/53573_rastut_tsenyi_na_fasol_/ http://www.kazakh-zerno.kz/novosti/mirovoj-rynok-selskogo-khozyajstva-i-prodovolstviya/225356-kyrgyzskaya-fasol-zhertva-mirovoj-geopolitiki

http://caa-network.org/archives/7555 


\section{Annex 1 - Regulatory framework and authorized state bodies responsible for plant protection and seed improvement}

In accordance with the Laws of the Kyrgyz Republic "On Plant Chemicalization and Protection" dated December 29, 1998 and "On Plant Quarantine" dated June 27, 1996, the State Department for Plant Chemicalization, Protection and Quarantine (DPCPQ) implements the system of state measures aimed to protect agricultural crops from pests, diseases and weeds, protect the territory of the Kyrgyz Republic from the penetration of quarantine organisms from other countries, as well as implements quarantine measures. The DPCPQ is the authorized executive body in charge of overseeing the control of the safe handling of pesticides and agrochemicals, phytosanitary, agrochemical situation and the implementation of quarantine measures. Cultivated area are surveyed annually. Since bean-related pests and diseases are not quarantineable, rigorous research and plant protection activities have not been implemented.

The Republican State Seed Inspection (RSSI) of the Ministry of Agriculture, Water Resources and Processing Industry of the Kyrgyz Republic was established in 1928 as a control and seed station. Currently, the RSSI has carried out 14 interdistrict and three district state seed inspections with 77 staff supervising the compliance of seed farms with the state standards for the production, storage and sale of seed and planting stock of agricultural crops in the Kyrgyz Republic. The activity of state seed inspections is regulated by the Law of the Kyrgyz Republic "On Seeds" dated June 19, 1997, the Law of the Kyrgyz Republic "On Amendments and Additions to the Law of the Kyrgyz Republic "On Seeds" dated January 8, 2007 and other normative legal acts of the Kyrgyz Republic.

The activity of the RSSI is mainly aimed at organizing state control over the compliance with state standards and rules in the production, storage and sale of seed and planting stock of agricultural crops, and to implement state measures for seed control and the certification of seeds and planting stock. At the moment, according to RSSI reports ${ }^{66}$, the activities mainly relate to legumes.

The Central and Osh specialized toxicological control and plant quarantine laboratories are also subordinated to the DPCPQ. The RSSI is in charge of the Central laboratory of the Republican State Seed Inspection, which in November 2005 was accredited to ISTA (International Association for Testing Seeds).

The main normative legal acts governing the phytosanitary area in Kyrgyzstan when exporting beans are in Table 22 below.

66 http://agroprod.kg/index.php?pageID $=68$ 
Table 22. Normative legal acts governing phytosanitary issues when exporting beans

\begin{tabular}{|c|c|}
\hline NLAs & Description \\
\hline $\begin{array}{c}\text { The Law No. } 2 \text { of the Kyrgyz Republic "On Plant } \\
\text { Quarantine" dated January 12, } 2015\end{array}$ & $\begin{array}{c}\text { Establishes a legal basis for regulation in } \\
\text { the field of plant quarantine, determines } \\
\text { powers of the state executive bodies, as } \\
\text { well as basic rights and obligations of } \\
\text { individuals and legal entities in the field } \\
\text { of plant quarantine }\end{array}$ \\
\hline $\begin{array}{l}\text { The Regulations on the State Inspectorate for } \\
\text { Veterinary and Phytosanitary Safety under the } \\
\text { Government approved by the Resolution No. } 256 \text { of } \\
\text { the GoKR dated May 7, } 2013\end{array}$ & $\begin{array}{l}\text { Goals, objectives and functions of the } \\
\text { state inspection, organization of the State } \\
\text { Inspectorate's activities }\end{array}$ \\
\hline $\begin{array}{l}\text { Quarantine phytosanitary rules of the Kyrgyz } \\
\text { Republic approved by the Resolution No. } 376 \text { of the } \\
\text { Government of the Kyrgyz Republic dated June 18, } \\
2015\end{array}$ & $\begin{array}{l}\text { Prevention or limitation of economic } \\
\text { damage due to penetration and rooting } \\
\text { of pests that do not exist on the territory } \\
\text { of the Kyrgyz Republic, as well as an } \\
\text { increase in the population of pests }\end{array}$ \\
\hline $\begin{array}{l}\text { The Regulations on the procedure for issuing } \\
\text { phytosanitary, re-export phytosanitary and } \\
\text { quarantine certificates approved by the Resolution } \\
\text { No. } 376 \text { of the Government of the Kyrgyz Republic } \\
\text { dated June } 18,2015\end{array}$ & $\begin{array}{l}\text { Establishes the order of organization of } \\
\text { works on the issuance of phytosanitary, } \\
\text { re-export phytosanitary and quarantine } \\
\text { certificates for plant shipments, products } \\
\text { of plant origin and other quarantineable } \\
\text { materials }\end{array}$ \\
\hline $\begin{array}{l}\text { The list of quarantineable products of } \\
\text { quarantineable cargoes, quarantineable materials, } \\
\text { quarantineable goods subject to quarantine } \\
\text { phytosanitary control (supervision) at the customs } \\
\text { border of the Customs Union and the customs } \\
\text { territory of the Customs Union approved by the } \\
\text { Resolution No. } 583 \text { of the Government of the Kyrgyz } \\
\text { Republic dated October } 7,2014\end{array}$ & $\begin{array}{l}\text { Lists products in accordance with FEA } \\
\text { CN codes }\end{array}$ \\
\hline $\begin{array}{l}\text { The regulations on assessing conformity of } \\
\text { facilities and ensuring safety measures in the } \\
\text { field of veterinary medicine, plant quarantine, } \\
\text { epidemiology, sanitation and ecology in the } \\
\text { Kyrgyz Republic approved by Resolution No. } 901 \\
\text { of the Government of the Kyrgyz Republic dated } \\
\text { December 30, } 2006\end{array}$ & $\begin{array}{l}\text { Defines sanitary-epidemiological, } \\
\text { veterinary-sanitary, phytosanitary } \\
\text { and environmental measures and } \\
\text { procedures for conformity assessment } \\
\text { in the field of sanitary-epidemiological, } \\
\text { veterinary-sanitary, phytosanitary } \\
\text { and environmental well-being on the } \\
\text { territory of the Kyrgyz Republic }\end{array}$ \\
\hline $\begin{array}{c}\text { Technical Regulation CU } 015 / 2011 \text { "On grain } \\
\text { safety" approved by the Decision No. } 874 \text { of } \\
\text { the Commission of the Customs Union dated } 9 \\
\text { December } 2011\end{array}$ & $\begin{array}{l}\text { Establishes unified requirements for } \\
\text { grain that are mandatory for application } \\
\text { and compliance on the unified customs } \\
\text { territory of the Customs Union }\end{array}$ \\
\hline
\end{tabular}

Source: Database of legal information "Toktom" http://toktom.kg/

The Law of the Kyrgyz Republic "On plant quarantine" aims to ensure protection of plants on the territory of the Kyrgyz Republic from the penetration and spread of quarantineable objects, as well as to prevent damage from the spread of quarantineable objects. In accordance with Article 4 of the above Law, the Government of the Kyrgyz Republic is in charge of the implementation 
of a unified state policy in the field of plant quarantine in the Kyrgyz Republic and assigning a state executive body authorized in the field of plant quarantine.

The state quarantine phytosanitary control is implemented at checkpoints across the state borders of the Kyrgyz Republic - for quarantineable products, this is done in places of storage and processing of quarantineable products while for quarantineabe facilities and in other places this is determined by the Government of the Kyrgyz Republic.

Phytosanitary control is implemented by the examination and inspection of products through taking samples and assays, quarantine phytosanitary decontamination and testing. Export of quarantineable products is permitted only with a phytosanitary certificate issued based on the exporter's application and conclusion on the phytosanitary status of quarantineable products. Samples and assays are tested by the quarantine labaratories subordinated to the DPCPQ.

Quarantine phytosanitary rules of the Kyrgyz Republic approved by Resolution No. 376 of the GoKR dated June 18, 2016 determine the requirements for quarantineable products depending on their type, i.e. general provisions, seed and planting material, cereals, fruit and vegetables. In addition, the rules determine the list of the quarantine characteristics of pests for quarantineable products, and the requirements for the formalization of phytosanitary and re-export phytosanitary certificates. The above list mentions no diseases and pests of bean and other legumes.

The issuance of phytosanitary and re-export phytosanitary certificates is governed by the Regulations on the procedure for issuance of phytosanitary, re-export phytosanitary and quarantine certificates approved by Resolution No. 376 of the Government of the Kyrgyz Republic dated June 18, 2015. Phytosanitary certification includes the following procedures: the establishment or confirmation of the status "free from regulated pests", places or areas of quarantineable goods production intended for export from the territory of the Kyrgyz Republic; quarantine phytosanitary disinfection of quarantineable products, places of their storage, processing, and vehicles; inspection of quarantineable products batch and vehicles at the place of loading; laboratory examination of samples (assays) of quarantineable products. This activity is implemented by the DPCPQ.

Inspection of quarantineable products and vehicles includes: checking documents; verification of authenticity and integrity of the products batch, sampling of products; visual inspection of samples; sealing of the vehicle cargo compartments; and preparing the act of inspection.

A phytosanitary certificate is issued by the authorized body for a batch of quarantineable goods produced in the territory of the Kyrgyz Republic and intended for export abroad in accordance with the phytosanitary requirements of the importing country. The quarantine certificate is issued by the authorized body for each batch of high-risk quarantineable goods produced in the quarantine phytosanitary zone, the regime of which provides for a mandatory quarantine certificate for this type or category of products; seed and planting materials imported into the territory of the Kyrgyz Republic; seed and planting materials produced and released for circulation on the territory of the Kyrgyz Republic. Forms of certificates are in the Annex to the Regulations. These certificates are issued for a period of 15 days in Russian or Kyrgyz languages, unless otherwise provided for by international treaties.

The following documents shall be submitted for obtaining a certificate: a hard copy or electronic application to the territorial subdivisions of the authorized body; an extract from the agreement (contract) on the basis of which the products are exported; the decision of the authorized body to assign the status "free from regulated pests" to a certain production place or area; the act of 
quarantine phytosanitary disinfection; the inspection certificate; the certificate of quarantine phytosanitary examination in accordance with the certification scheme; national requirements or requirements of the importing country. In addition, if the certification scheme provides for laboratory testing, an average sample compiled using selected samples of the cargo, packed in a special safe package and accompanied by a label in the form as prescribed by the guidelines shall be sent to the laboratory of the authorized body. An application for issuance of a phytosanitary, re-export phytosanitary and quarantine certificate is considered and registered by the territorial subdivision of the authorized body within 30 minutes from the moment of application.

In accordance with the Regulations on assessing conformity of objects and ensuring safety measures in the field of veterinary, plant quarantine, epidemiology, sanitation and ecology in the Kyrgyz Republic approved by Resolution No. 901 of the Government of the Kyrgyz Republic dated 30 December 2006, bean-related pests and diseases are not included in the list of pests, diseases and weeds of quarantine importance for the Kyrgyz Republic. In addition, the requirements for hay and planting material of beans allow for no living pests and their larvae on crops in any form. Based on monitoring and analysis of media and online resources, there were no cases of delay in bean supplies resulting from phytosanitary requirements in Kyrgyzstan over the past 4 years. This corresponds to the responses of representatives of the business community.

\section{Annex 2 - Tariff and non-tariff barriers at potential export markets for kidney beans}

Requirements for imported bean (FEA CN code 071333 ) in different countries - key bean importers are listed in Table 23

Table 23. Requirements for exported products established by potential export markets (tariff and non-tariff barriers)

\begin{tabular}{|c|c|c|c|}
\hline Country & Barriers & $\begin{array}{c}\text { Non-tariff barriers (including sanitary and } \\
\text { phytosanitary barriers) }\end{array}$ & Source \\
\hline Turkey & $\begin{array}{c}\text { Tax of 19.3\% } \\
\text { Ministry of } \\
\text { Economy } \\
\text { of Turkey } \\
\text { (documents } \\
\text { are available } \\
\text { only in Turkish } \\
\text { language) }\end{array}$ & $\begin{array}{c}\text { Translation into Turkish language is } \\
\text { mandatory. In addition, all industrial } \\
\text { products must be officially registered. All } \\
\text { packages, boxes and bales must have: } \\
\text { Transportation label } \\
\text { Number } \\
\text { Dimensions } \\
\text { A certificate stating that the product is } \\
\text { not infected with Bovine Spongiform } \\
\text { Encephalopathy }\end{array}$ & $\begin{array}{c}\text { http://www.resmi- } \\
\text { gazete.gov.tr/eskil- } \\
\text { er/2015/12/20151231M1. }\end{array}$ \\
pdf \\
\end{tabular}




\begin{tabular}{|c|c|c|c|}
\hline India & $\begin{array}{l}\mathbf{3 0 \%} \text { tax on } \\
\text { Common bean, } \\
\text { including } \\
\text { white small- } \\
\text { seed bean } \\
\text { (Phaselous } \\
\text { vulgaris), } 0713 \\
3300 \\
\\
\text { Central Excise } \\
\text { and Customs } \\
\text { Council of } \\
\text { India }\end{array}$ & $\begin{array}{c}\text { Submit a permit for import / } \\
\text { phytosanitary certificate and registration } \\
\text { of the importer } \\
\text { Submit a test report / non-objection } \\
\text { certificate of the Food Safety and } \\
\text { Standards Authority of India (FSSAI) or } \\
\text { phytosanitary body } \\
\text { Ensure the compliance with storage } \\
\text { conditions, physical properties and } \\
\text { labelling } \\
\text { Obtain a certificate of absence of } E \text {. coli } \\
\text { bacteria in fresh vegetables } \\
\text { 2003 Order on plant quarantine. } \\
\text { Food Safety \& Standards Act } 2006 \text { \& CBEC } \\
\text { CIR 3/11 \& Para } 2.1 \text { OF 58/01 \& CBEC } \\
\text { Instr DT 08.06.11 }\end{array}$ & $\begin{array}{l}\frac{\text { http://www.cbec.gov.in/ }}{\text { resources//htdocs-cbec/ }} \\
\frac{\text { customs/cs-tariff2015-16/ }}{\text { chap-7.pdf }}\end{array}$ \\
\hline EU & $\begin{array}{l}\text { Preferential } \\
\text { tariff of } 0 \% \\
\text { for category } \\
\text { 0713 from } \\
\text { Kyrgyzstan; } \\
\text { According to } \\
\text { TARIC - the } \\
\text { unified tariff } \\
\text { regime of the } \\
\text { EU } \\
\text { However, } \\
\text { a separate } \\
\text { VAT can be } \\
\text { imposed, } \\
\text { which is not } \\
\text { reflected } \\
\text { online }\end{array}$ & $\begin{array}{l}\text { A certificate stating that the product is } \\
\text { not infected with Bovine Spongiform } \\
\text { Encephalopathy }\end{array}$ & 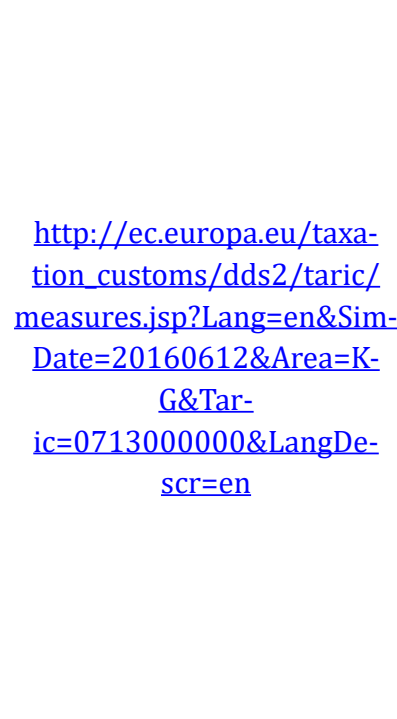 \\
\hline China & $3.8 \%$ tariff & $\begin{array}{c}\text { A certificate stating that the product is } \\
\text { not infected with Bovine Spongiform } \\
\text { Encephalopathy, Avian Influenza or African } \\
\text { Swine Fever }\end{array}$ & $\begin{array}{l}\frac{\text { https://www.wto.org/eng- }}{\text { lish/thewto e/countries e/ }} \\
\text { china e.htm }\end{array}$ \\
\hline $\begin{array}{l}\text { Kazakh- } \\
\text { stan }\end{array}$ & $\begin{array}{l}\mathbf{1 0 \%} \text { tariff } \\
\text { Kazakhstan } \\
\text { applies UCT of } \\
\text { the EAEC }\end{array}$ & $\begin{array}{l}\text { A certificate stating that the product is } \\
\text { not infected with Bovine Spongiform } \\
\text { Encephalopathy }\end{array}$ & $\begin{array}{l}\text { http://www.eurasiancom- } \\
\text { mission.org/en/act/trade/ } \\
\text { catr/Pages/default.aspx }\end{array}$ \\
\hline Russia & $\begin{array}{l}\mathbf{1 0 \%} \text { tariff } \\
\text { Russia applies } \\
\text { UCT of the EAEC }\end{array}$ & $\begin{array}{l}\text { A certificate stating that the product is } \\
\text { not infected with Bovine Spongiform } \\
\text { Encephalopathy }\end{array}$ & $\begin{array}{l}\text { http://www.rusimpex.ru/in- } \\
\text { dex1.htm?varurl=Content e/ } \\
\text { Custom/Poshlin/index.htm }\end{array}$ \\
\hline Pakistan & $\begin{array}{l}\mathbf{2 \%} \text { tariff } \\
\text { Federal } \\
\text { Revenues } \\
\text { Council - } \\
\text { Government of } \\
\text { Pakistan }\end{array}$ & $\begin{array}{l}\text { The importer must provide the Online } \\
\text { Goods Declaration via the Computerized } \\
\text { Customs System of Pakistan or provide a } \\
\text { hard copy of the declaration at the customs } \\
\text { check point, as applicable. } \\
\text { A certificate stating that the product is } \\
\text { not infected with Bovine Spongiform } \\
\text { Encephalopathy }\end{array}$ & $\begin{array}{c}\text { http://download1.fbr.gov.pk/ } \\
\frac{\text { Docs/20157101374641856Re- }}{\text { updated5thScheduleandCUS- }} \\
\frac{\text { TOMTariff.pdf }}{\text { page 19 }}\end{array}$ \\
\hline
\end{tabular}




\begin{tabular}{|c|c|c|c|}
\hline Iran & $32 \%$ tariff & $\begin{array}{l}\text { Failed to find verified information on non- } \\
\text { tariff barriers }\end{array}$ & $\begin{array}{l}\frac{\mathrm{http}: / / \text { www.iranpartner. }}{\underline{\text { com/images/pdf/section2. }}} \\
\underline{\text { pdf }}\end{array}$ \\
\hline $\begin{array}{l}\text { South } \\
\text { Korea }\end{array}$ & $27 \%$ tariff & $\begin{array}{c}\text { Application for import to be submitted to } \\
\text { the Korea Food and Drug Administration: } \\
\text { Sanitary certificate from the country of } \\
\text { origin } \\
\text { The list of products } \\
\text { and processing } \\
\text { Detailed information about the production } \\
\text { Translation of documents into Korean } \\
\text { language } \\
\text { Cargo declaration (IP Handling certificate) } \\
\text { of the country of origin } \\
\text { Copy of the reason for the selected period } \\
\text { of importation } \\
\text { Certificate of safety of the imported goods }\end{array}$ & 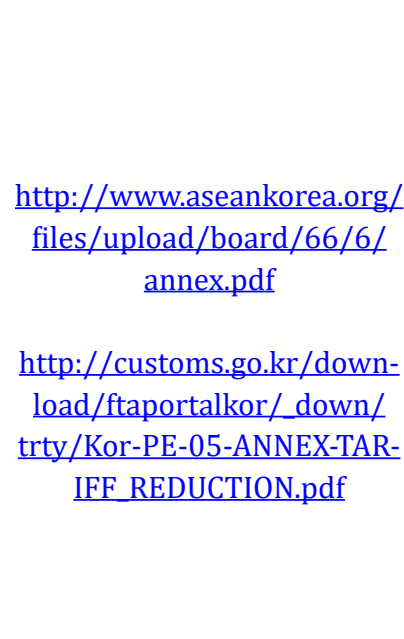 \\
\hline
\end{tabular}

* Iran is deemed as a potential export market for bean from Kyrgyzstan, however, data on legumes consumption and production are not available. 
